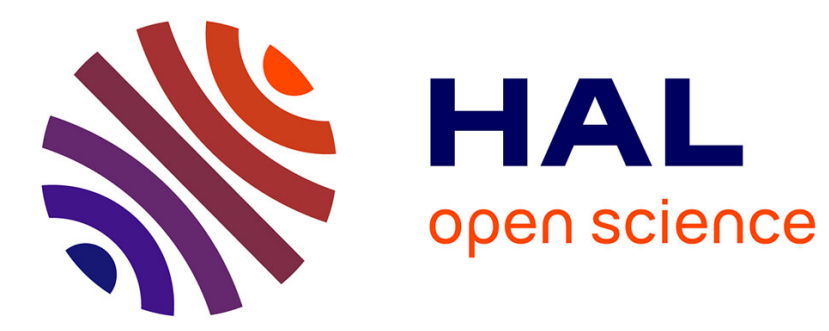

\title{
New records of water mites from Southeast Asia (Acari: Hydrachnidia) with the description of two new genera and 12 new species
}

\author{
V. Pesic, H. Smit
}

\section{- To cite this version:}

V. Pesic, H. Smit. New records of water mites from Southeast Asia (Acari: Hydrachnidia) with the description of two new genera and 12 new species. Acarologia, 2016, 56 (3), pp.393-433. 10.1051/acarologia/20162251 . hal-01547323

\section{HAL Id: hal-01547323 \\ https://hal.science/hal-01547323}

Submitted on 26 Jun 2017

HAL is a multi-disciplinary open access archive for the deposit and dissemination of scientific research documents, whether they are published or not. The documents may come from teaching and research institutions in France or abroad, or from public or private research centers.
L'archive ouverte pluridisciplinaire HAL, est destinée au dépôt et à la diffusion de documents scientifiques de niveau recherche, publiés ou non, émanant des établissements d'enseignement et de recherche français ou étrangers, des laboratoires publics ou privés.

\section{(ㅇ)(1) $\$$}

Distributed under a Creative Commons Attribution - NonCommercial - NoDerivatives $\mid 4.0$ 


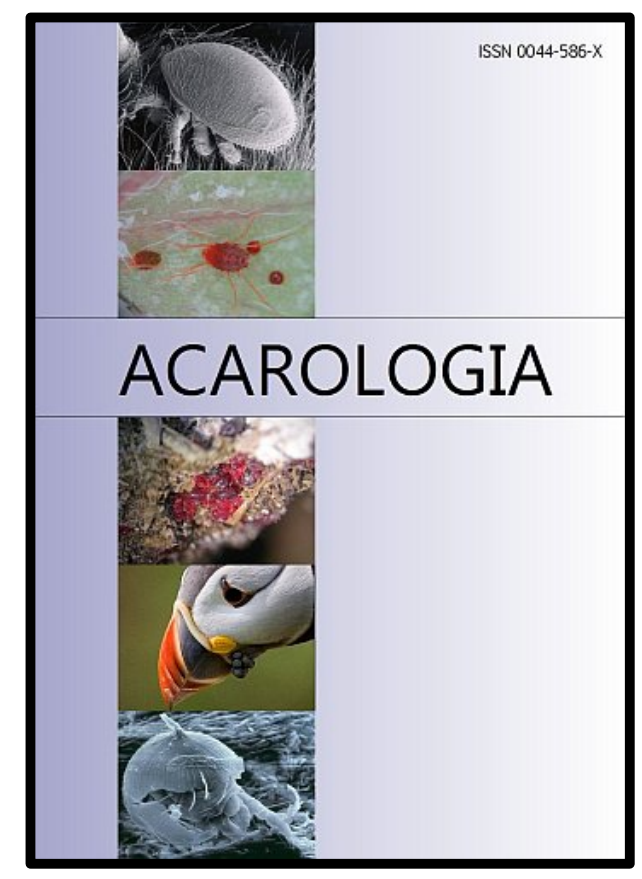

\section{ACAROLOGIA}

A quarterly journal of acarology, since 1959

Publishing on all aspects of the Acari

All information:

http://www1.montpellier.inra.fr/CBGP/acarologia/ acarologia@supagro.inra.fr

\section{OPEN ACCESS}

\section{Acarologia is proudly non-profit, with no page charges and free open access}

Please help us maintain this system by encouraging your institutes to subscribe to the print version of the journal and by sending us your high quality research on the Acari.

Subscriptions: Year 2017 (Volume 57): $380 €$ http://www1.montpellier.inra.fr/CBGP/acarologia/subscribe.php

Previous volumes (2010-2015): $250 € /$ year (4 issues)

Acarologia, CBGP, CS 30016, 34988 MONTFERRIER-sur-LEZ Cedex, France

The digitalization of Acarologia papers prior to 2000 was supported by Agropolis Fondation under the reference ID 1500-024 through the « Investissements d'avenir » programme

(Labex Agro: ANR-10-LABX-0001-01)
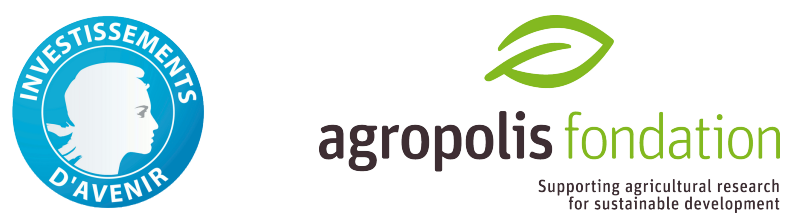

Acarologia is under free license and distributed under the terms of the

Creative Commons-BY-NC-ND which permits unrestricted non-commercial use, distribution, and reproduction in any medium, provided the original author and source are credited. 


\title{
New records of water mites from Southeast Asia (Acari: Hydrachnidia) with the description of two new genera and 12 new species
}

\author{
Vladimir PEŠIĆ ${ }^{1}$ and Harry SMIT ${ }^{2}$ \\ (Received 24 February 2016; accepted 22 April 2016; published online 22 July 2016) \\ ${ }^{1}$ Department of Biology, University of Montenegro, Cetinjski put b.b., 81000 Podgorica, Montenegro. vladopesic@gmail.com \\ ${ }^{2}$ Naturalis Biodiversity Center, P.O. Box 9517, 2300 RA Leiden, The Netherlands. harry.smit@naturalis.nl
}

ABSTRACT - Twenty-one species of water mites (Acari, Hydrachnidia) were collected in 2015 during a hydrobiological survey conducted by Burkhard Scharf in Vietnam, Laos and Cambodia. Twelve taxa new to science are described, representing the families Torrenticolidae (Torrenticola laosensis n. sp.), Limnesiidae (Limnesia scharfi $\mathbf{n}$. sp.), Hygrobatidae (Vietnobates oryzae n. gen., n. sp.), Pionidae (Schwoerbelia pioniformis n. gen., n. sp., Forelia gereckei n. sp.), Aturidae (Hexaxonopsis laosensis n. sp., H. cambodiensis n. sp., H. angkoriensis n. sp., Javalbia vietnamica n. sp., Sinaxonopsis laosensis n. sp.), Athienemanniidae (Africasia purpurea n. sp.) and Arrenuridae (Arrenurus contortus n. sp.).

KEYWORDS - Water mites; taxonomy; new species; Oriental region; Vietnam; Laos; Cambodia

\section{INTRODUCTION}

In April and May 2015, Burkhard Scharf (Bremen, Germany) conducted a hydrobiological survey in Vietnam, Laos and Cambodia. This paper aims to present the complete acarological results of his survey and to enlarge our knowledge of the water mite presence and distribution in SE Asia. Over the last years significant effort was done to explore water mites of Vietnam and up to now, 16 species of water mites are reported (see Table 1 and reference therein). On the other hand, the water mite fauna of Laos was known from two species of Hygrobates salamandrarum-group ( $H$. ancistrophorus Goldschmidt \& Koehler, 2007 and H. forcipifer Goldschmidt \& Koehler, 2007), one species each of the genera Piona (P. allodadayi Jin, 1997) and Neumania (N. dolichotricha Jin, 1997). Finally, two species are known of the speciose genus Arrenurus: Arrenu- rus bicornicodulus Piersig, 1906 and A. corpuscularis Jin \& Wiles, 1996. Up to now, no water mites are reported from Cambodia.

In this paper, descriptions of twelve new species and two genera new for science are given.

\section{MATERIALS AND METHODS}

The samples were collected using a net with a 200 $\mu \mathrm{m}$ mesh width and then sieved with a $5 \mathrm{~mm}$ mesh size to remove the coarse sediment and keep the fine fraction. Water mites were separated from the sediment using the so-called blowing method (Scharf and Viehberg 2014) and preserved in 96\% ethanol. Later on, water mites were transferred to Koenike-fluid and dissected as described elsewhere (e.g. Gerecke et al. 2007). All material has been collected by Burkhard Scharf. Unless stated otherwise 
TABLE 1: List of water mites known from Vietnam.

\begin{tabular}{ll}
\hline Hydrodroma vietnamica Tuzovskij, 2015 & Tuzovskyi (2015) \\
Sigthoria asiatica Tuzovskij, 2014 & Tuzovskyi (2014) \\
Monatractides vietnamensis Tuzovskij, 2009 & Tuzovskij (2009b) \\
Torrenticola vietnamica Tuzovskij, 2013 & Tuzovskij (2013a) \\
Torrenticola anophthalma Pešić \& Gerecke, 2014 & Pešić and Gerecke (2014) \\
Stygotorrenticola coniseta Pešić \& Gerecke, 2014 & Pešić and Gerecke (2014) \\
Acucapito vietnamensis Tuzovskij, 2009 & Tuzovskij (2009a) \\
Limnesia vietnamensis Tuzovskij, 2013 & Tuzovskij (2013a) \\
Raptorhydracarus tomasini Pešić \& Gerecke, 2014 & Pešić and Gerecke (2014) \\
Hygrobates ancistrophorus Goldschmidt \& Koehler, 2007 & Goldschmidt and Koehler (2007) \\
Hygrobates forcipifer Goldschmidt \& Koehler, 2007 & Goldschmidt and Koehler (2007) \\
Hygrobates gusakovi Tuzovskij, 2013 & Tuzovskij (2013) \\
Neumania disetoides Tuzovskij, 2013 & Tuzovskij (2013b) \\
Neumania vietnamica Tuzovskij, 2013 & Tuzovskij (2013b) \\
Albaxona gusevi Tuzovskij, 2013 & Tuzovskij (2013a) \\
Nilotonia sketi Pešić, 2013 & Pešić (2013) \\
Africasia vietnamitica Pešić \& Gerecke, 2014 & Pešić and Gerecke (2014)
\end{tabular}

coordinates were obtained with a GPS. Holotypes of new species are deposited in the Naturalis Biodiversity Center in Leiden (RMNH).

The composition of the material is given as: males/females/deutonymphs or adults/deutonymphs. All measurements are given in $\mu \mathrm{m}$. The following abbreviations are used: Ac-1 - first acetabulum; alt. - altitude; a.s.l. - above sea level; Cx-I - first coxae; Cxgl-IV - coxoglandularia 4; Dgl-4 - dorsoglandularia 4; H - height; I-L-4-6 fourth-sixth segments of first leg; L - length; Lgl-4 lateroglandularia 4; $\mathrm{mL}$ - medial length; P-1-P-5 palp segment 1-5; Vgl-1 - ventroglandularia 1; W width.

\section{SYSTEMATIC PART \\ Family Hydrachnidae Leach, 1815 Genus Hydrachna Müller, 1776}

Hydrachna simulans Marshall, 1928

Material examined - Cambodia, 15-34-1 Angkor, ancient swimming pool of the king (named: Srah Srang acc. to Google Earth, 2015), 132 $5^{\prime} 56.3^{\prime \prime} \mathrm{N}$, $103^{\circ} 54^{\prime} 18.5^{\prime \prime E}$, alt. $27 \mathrm{~m}$ a.s.l., water depth $0.1 \mathrm{~m}$, substrate: sand covered by a thin layer of detritus, some submersed macrophytes; 23.iv.2015, 1/0/0.

Remarks - Lundblad (1969) placed Hydrachna similis Cook, 1967, H. mysorensis Cook, 1967 and H. kloomi Imamura, 1964 in synonymy under H. simulans. This treatment was followed by Pešić et al. (2010), and by us here.

Distribution - China, Thailand, India, Cambodia.

Family Torrenticolidae Piersig, 1902
Genus Monatractides K. Viets, 1926
Subgenus Monatractides K. Viets, 1926

Monatractides (Monatractides) sp. (Figure 1)

Material examined - Vietnam, 15-44-1 Bach Má National Park, brook with a pool behind a natural barrier, $16^{\circ} 11^{\prime} 15.5^{\prime \prime} \mathrm{N}, 105^{\circ} 50^{\prime} 54.7^{\prime \prime} \mathrm{E}$, alt. $1130 \mathrm{~m}$ a.s.l., water depth $0.2 \mathrm{~m}$, substrate: leaves in a lentic bay, 2.v.2015, 0/1/0 (mounted).

Morphology - Female: Idiosoma elongatedoval; shoulder plates only slightly longer than frontal plates; frontal margin medially straight between large anterolaterally pointed apodemes (Fig- 


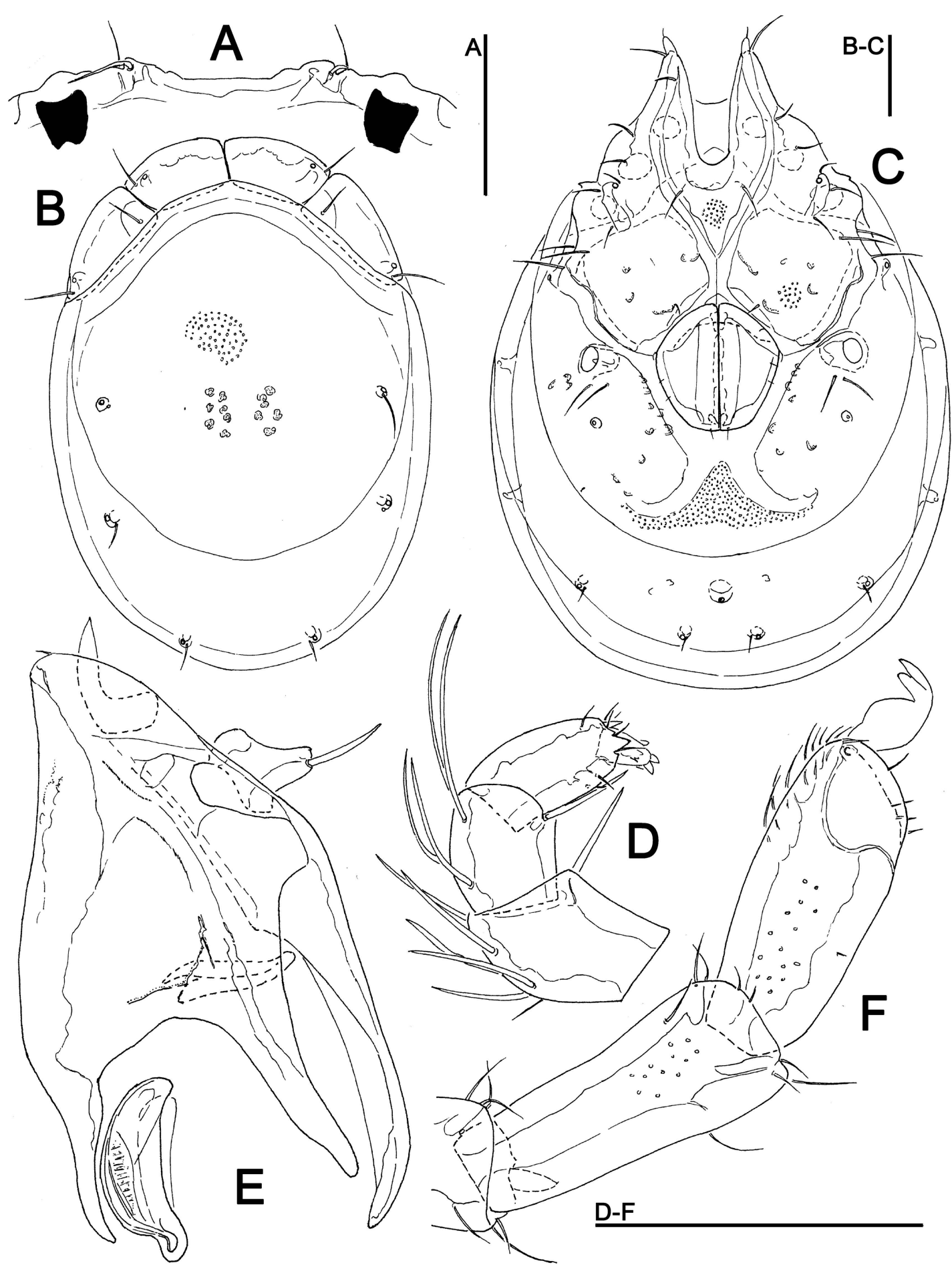

Figure 1: Monatractides (Monatractides) sp., female, Bach Má National Park, Vietnam: A - frontal margin of idiosoma, dorsal view; B dorsal shield; C - idiosoma, ventral view; D - palp, lateral view (P-1 lacking); E - gnathosoma; F - I-L-5 and -6. Scale bars - $100 \mu \mathrm{m}$. 
ure 1A); Cxgl-4 located far anteriorly, near tips of Cx-I; gnathosomal bay deep, U-shaped; suture lines of Cx-IV distinct, originating from lateral edge of genital field and extending posteriorly beyond posterior margin of genital field; genital field large and pentagonal in shape, anteriorly enlarged, laterally straight or slightly convex, tapering posteriorly; excretory pore and Vgl-2 well separated from the line of primary sclerotization, Vgl-2 posterior to excretory pore; gnathosoma with long dorsal apodemes, rostrum truncated (Figure 1E); ventral and dorsal setae of P-2 and P-3 relatively strong and long, P2 and P-3 distal margins without pointed tips, P-4 stout, ventral setae short, not reaching the tip of P-5 (Figure 1D).

Measurements - Idiosoma L 792, W 567; dorsal shield L 663, W 459, L/W ratio 1.44; dorsal plate L 606; shoulder plate L 150 - 156, W $73-75$, L/W ratio 2.0-2.1; frontal plate $\mathrm{L} 130-131, \mathrm{~W} 72-74$, $\mathrm{L} / \mathrm{W}$ ratio $1.76-1.8$; $\mathrm{L}$ shoulder/frontal plate ratio 1.15 - 1.2. Gnathosomal bay L 141, Cx-I total L 256, Cx-I mL 116, Cx-II+III mL 54; ratio Cx-I L/CxII+III mL 2.21; Cx-I mL/Cx-II+III mL 4.8. Genital field L/W 156/146, ratio 1.07; egg maximum diameter 203; distance genital field-excretory pore 209, genital field-caudal idiosoma margin 325 . Chelicera total $\mathrm{L} 208$; palp total $\mathrm{L} 185, \mathrm{dL} / \mathrm{H}, \mathrm{dL} / \mathrm{H}$ ratio: $\mathrm{P}-$ 1, 26/25, 1.07; P-2, 54/39, 1.4; P-3, 39/32, 1.22; P4, 46/23, 2.0; P-5, 20/11, 1.9; L P-2/P-4 ratio 1.17. Legs: dL of I-L-4-6: 102, 103, 103; I-L-6 H 84, dL/H I-L-6 ratio 1.22 .

Remarks - The single female from Vietnam resembles superficially specimens tentatively included in the so-called M. macroporus (K. Viets, 1935)-complex (see Wiles 1991, Pešić and Smit 2009, 2014b). This group includes several similar species known from SE Asia, i.e., M. angulatus (Walter, 1928) (India), M. macroporus (K. Viets, 1935) (Sumatra, Java, Borneo), M. major (K. Viets, 1935) (Java), M. longiventris (Viets, 1939) (Java, Borneo), M. tranversalis (Lundblad, 1941) (Myanmar), M. nondescripta (Cook, 1966) (India), M. minor Wiles, 1991 (Malaysia) and M. epiales Pešić \& Smit, 2014b (Borneo). The specimen from our study differs in less narrower gnathosomal bay and somewhat shorter P-4 (L P-4/P-3 ratio $\approx 1.2$ ). In this character state, it agrees with M. minor Wiles, 1991 from Malaysia, a species differing in minor idiosoma and palp dimensions and four dorsoglandularia on the dorsal plate (Wiles 1991). Understanding the taxonomic position of the species of this complex species is not possible without the application of molecular techniques (Pešić and Smit 2014b), so introducing a new species on basis of a female will create more confusion given the present state of knowledge of this species.

\section{Monatractides (Monatractides) laosensis n. sp.} (Figure 2)

Material examined - Holotype male, dissected and slide mounted, Laos, 15-33-1, Kouangxi Waterfall, lentic bay within a pond behind a travertine barrier within the main brook, $19^{\circ} 44^{\prime} 55.9^{\prime \prime} \mathrm{N}, 101^{\circ} 59^{\prime} 33.4^{\prime \prime} \mathrm{E}$, alt. c. $490 \mathrm{~m}$ a.s.l., water depth $0.5 \mathrm{~m}$, substrate: travertine mud covered by some leaves, 24.iv.2015.

Diagnosis - (Female unknown). Medial margin of Cx-II/III relatively short; P-4 stout with a strong dorsomedial peg-like seta, located away from the distal edge.

Description - Male: Idiosoma roundish; shoulder platelet elongated (shoulder/frontal platelets L ratio 2.1-2.3); frontal platelet broad (L/W ratio 0.85 - 0.9); Cxgl-4 located far anteriorly, near tips of CxI; gnathosomal bay deep, U-shaped; medial margin of Cx-II/III relatively short; suture line of CxIV distinct, originating from lateral edge of genital field and extending posteriorly beyond posterior margin of genital field; genital field subrectangular, anteriorly enlarged and triangular; ejaculatory complex with small proximal chamber, carina anterior long; gnathosoma compact, rostrum truncated (Figure 2F); P-2 longer than P-4; distal margin of P-3 and $\mathrm{P}-4$ medially and laterally with several pointed extensions; P-4 stout with a strong dorsomedial peglike seta, located away from the distal edge, ventral setae slender and short, not reaching the tip of P-5 (Figures 2C-D).

Measurements - Dorsal shield L 394, W 278, $\mathrm{L} / \mathrm{W}$ ratio 1.42; shoulder plate $\mathrm{L} 147, \mathrm{~W} 59, \mathrm{~L} / \mathrm{W}$ ratio 2.5; frontal plate $\mathrm{L} 64-70, \mathrm{~W} 75-77, \mathrm{~L} / \mathrm{W}$ ratio $0.85-0.92$; L shoulder/frontal plate ratio 2.1-2.3. Ventral shield L 431, W 409; gnathosomal bay L 130, 


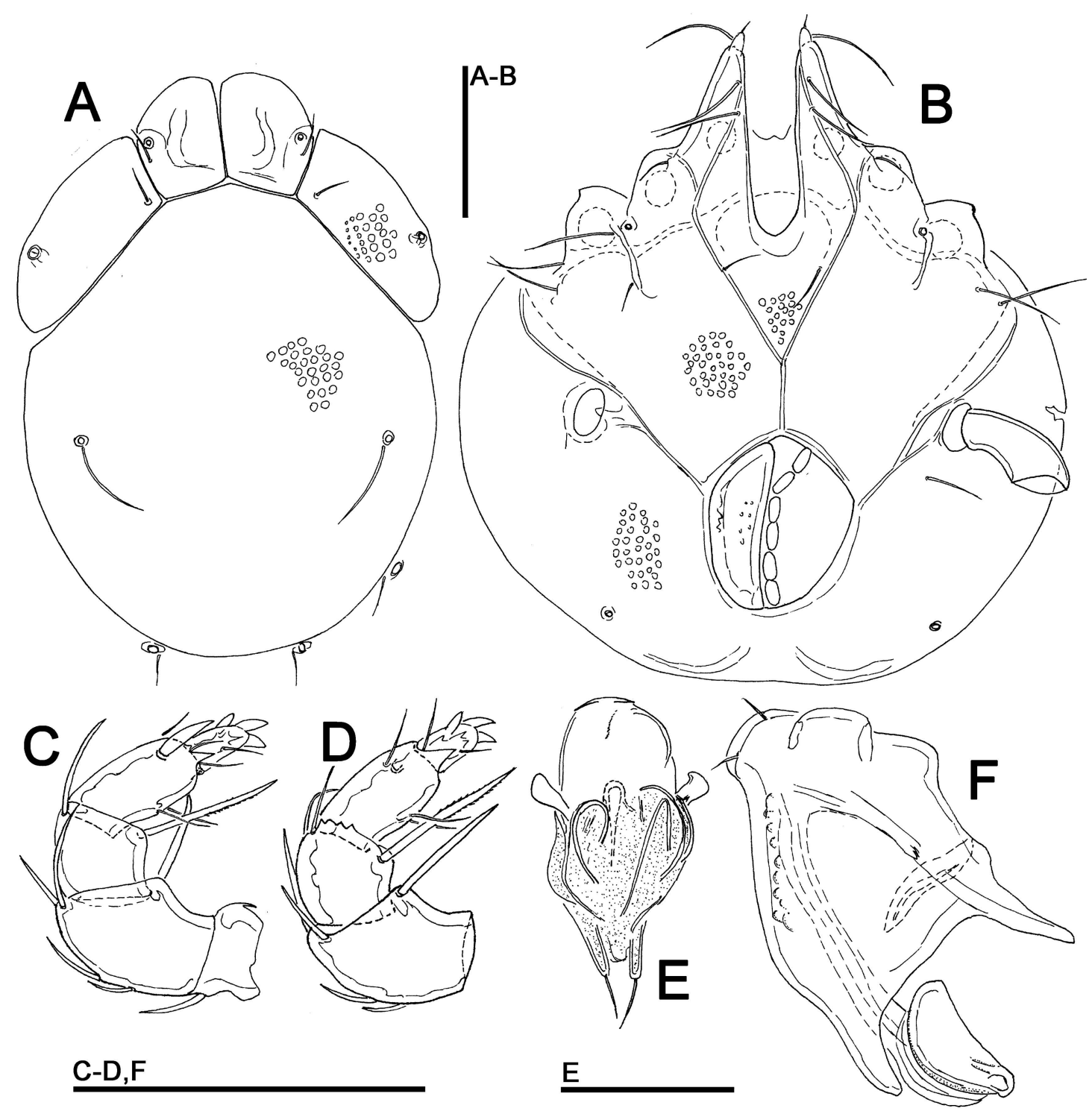

FIGURE 2: Monatractides (Monatractides) laosensis n. sp., male, Kauangxi Waterfall, Laos: A - dorsal shield; B - idiosoma, ventral view; C - palp, medial view; D - palp, lateral view (P-1 lacking); E - ejaculatory complex; F - gnathosoma. Scale bars - $100 \mu \mathrm{m}$. 
Cx-I total L 216, Cx-I mL 84, Cx-II+III mL 47; ratio Cx-I L/Cx-II+III mL 2.6; Cx-I mL/Cx-II+III mL 1.8. Genital field L/W 119/97, ratio 1.23; ejaculatory complex L 80. Gnathosoma vL 111; chelicera total L 138; palp total $\mathrm{L} 159, \mathrm{dL} / \mathrm{H}, \mathrm{dL} / \mathrm{H}$ ratio: $\mathrm{P}-1,20 / 25$, 0.8; P-2, 47/34, 1.37; P-3, 28/27, 1.03; P-4, 39/18, 2.2; P-5, 25/11, 2.3; L P-2/P-4 ratio 1.2. Legs: dL of I-L: 46, 42, 46, 52, 54, 57; I-L-6 H 23, dL/H I-L-6 ratio 2.5.

Female: Unknown.

Etymology - Named after the country where the new species was found.

Remarks - The new species is characterized by the strong dorsomedial peg-like seta, located away from the distal edge of P-4. Due to the latter character, Monatractides laosensis n. sp. resembles M. (M.) koenikei (K. Viets, 1916), a species known from West Africa. The latter species can be distinguished in having three pairs of knob-like protrusions at the lateral margins of the moderately deep gnathosomal bay, a longer medial suture line of Cx-II+III and somewhat stouter palp segments, especially P4 (see Pešić and Smit 2014a).

Distribution - Laos; known only from the locus typicus (Figure 25A).

\section{Family Limnesiidae Thor, 1900 Genus Limnesia Koch, 1836}

\section{Limnesia (Limnesia) scharfi n. sp.}

(Figures 3-4)

Type material - Holotype male, dissected and slide mounted, Vietnam, 15-44-1 Bach Má National Park, brook with a pool behind a natural barrier, $16^{\circ} 11^{\prime} 15.5^{\prime \prime} \mathrm{N}, 107^{\circ} 50^{\prime} 54.7^{\prime \prime} \mathrm{E}$, alt. $1130 \mathrm{~m}$ a.s.l., water depth $0.2 \mathrm{~m}$, substrate: leaves in a lentic bay; 2.v.2015. Paratypes: $2 / 1 / 0$, same data as holotype, one female dissected and slide mounted.

Diagnosis - Genital field with 2-3 small setae between Ac-1 and Ac-2; separation between Ac-1 and Ac-2 smaller than half the diameter of Ac-2; IVL-6 with two thick ventral setae.

Description - General features - Colour yellowbrownish; integument finely striated. Dorsum posteriorly with a small, rounded platelet (Figure 3A).
Cx-I medially separated, medial margins well developed, apodemes short. Cxgl-4 close to anterior margin of CX-III. Genital plates with small setae, 2-3 of them located between Ac-1 and Ac-2 (Figure 3B); acetabula large, separation between Ac-1 and Ac-2 smaller than half the diameter of Ac-2. Excretory pore between associated glandularia.

Gnathosoma with long dorsodistal projections (Figure 3E); P-2 ventral margin with a rounded distal protrusion, bearing a spine-like seta, not on a basal tubercle; P-4 slender, in anterior half ventrally with two setae (proximal seta shorter than distal one), each associated with a very small tubercle, and more distally one small seta (Figures 3C-D).

Legs - Numbers of swimming setae: III-L-4, 67; III-L-5, 9; IV-L-4, 4; IV-L-5, 5; IV-L-6 with two stout ventral setae, and a long subterminal seta (Figures $3 \mathrm{H}, 4 \mathrm{C}$ ), L ratio seta/IV-L-6 1.05-1.06; claws of I-III-L with dorsal and ventral clawlets (Figure 3G).

Measurements - Male (holotype): Idiosoma L/W 995/697; posterior dorsal plate L/W 39/47, ratio 0.83; coxal field L/W 303/525, L Cx-I+II 162, Cx-III+IV 255; genital plate L/W 139/204, ratio 0.68 , consisting of two flaps not fused at both ends; Ac-1 separated from Ac-2/3, separation half of diameter Ac-2; diameter Ac-1, 56-62; Ac-2, 48-49; Ac3, 45-47. Gnathosoma vL 108; chelicera total L 180, $\mathrm{H} 39, \mathrm{~L} / \mathrm{H}$ ratio 4.7 , L basal segment 123 , claw 60, $\mathrm{L}$ ratio basal segment/claw ratio 2.1. Palp: total $\mathrm{L}$ 267, dL/H, dL/H ratio: P-1, 15/29, 0.5; P-2, 63/46, 1.37; P-3, 61/39, 1.58; P-4, 97/22, 4.5; P-5, 31/11, 2.9; L P-2/4 ratio 0.65. Legs: dL of I-L-2-6: 52, 63, 79, 95, 109; L/H I-L-6 ratio 3.4; dL of IV-L: 115, 80, 99, 134, 127, 96; IV-L-6 subterminal seta L 91.

Female (paratype, n-1): Idiosoma L/W 1194/975; posterior dorsal plate 39/47, ratio 0.83; coxal field L/W 370/700, Cx-I+II 180, Cx-III+IV 303; genital field L/W 175/131, individual genital plate L/W 159/63, ratio 2.6, consisting of two flaps not fused at both ends; Ac-1 separated from Ac-2/3, separation half of diameter Ac-2; diameter Ac-1, 56; Ac-2, 53-56; Ac-3, 45-50. Gnathosoma vL 145; chelicera total L 223, H 49, L/H ratio 4.6, L basal segment 155, claw 68, L ratio basal segment/claw ratio 2.3. Palp: total L 302, dL/H, dL/H ratio: $\mathrm{P}-1,15 / 32,0.48 ; \mathrm{P}-2,75 / 54,1.4 ; \mathrm{P}-3,71 / 45$, 


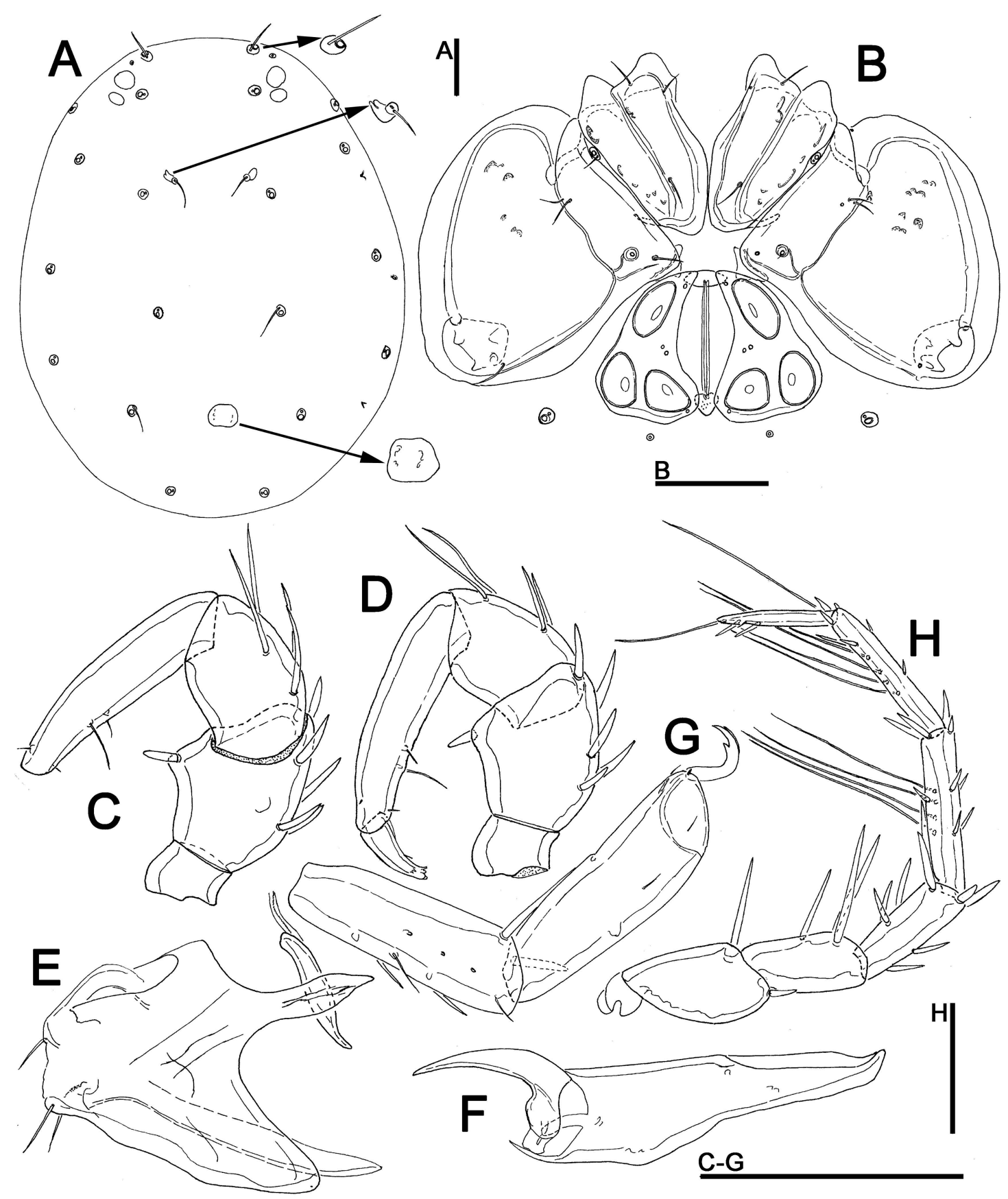

FIGURE 3: Limnesia (Limnesia) scharfi n. sp., male, Bach Má National Park, Vietnam: A - idiosoma, dorsal view; B - coxal and genital field; C - palp, medial view (P-5 lacking); D - palp, lateral view; E - gnathosoma; F - chelicera; G - I-L-5 and -6; H - IV-L. Scale bars $-100 \mu \mathrm{m}$. 
Pešić V. and Smit H.

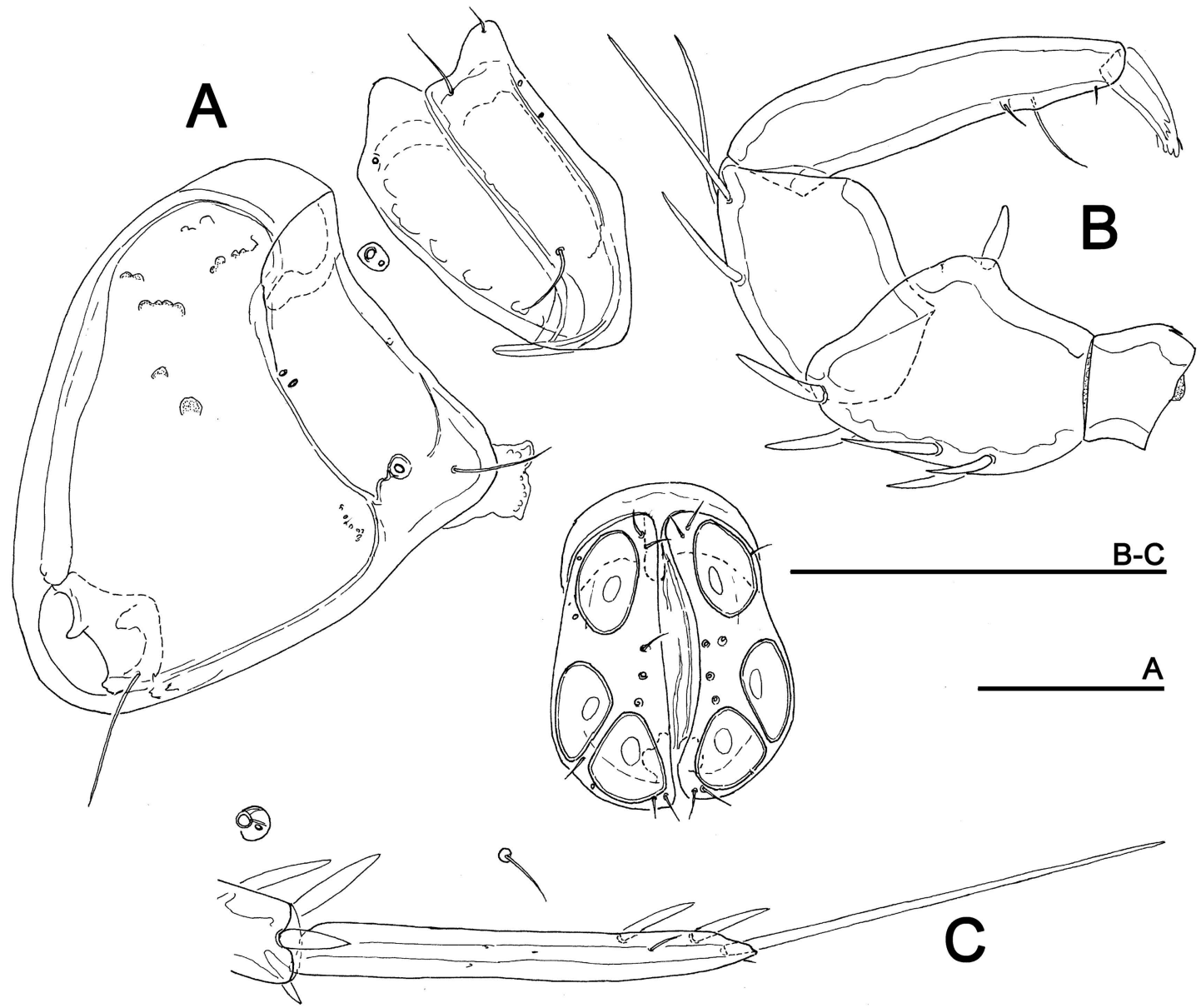

FIGURE 4: Limnesia (Limnesia) scharfi n. sp., female, Bach Má National Park, Vietnam: A - coxal and genital field; B - palp; C - IV-L-6. Scale bars $-100 \mu \mathrm{m}$. 
1.6; P-4, 109/25, 4.44; P-5, 32/11, 2.9; L P-2/4 ratio 0.69. Legs: dL of I-L-2-6: 64, 69, 91, 108, 115; L/H I-L-6 ratio 3.7; dL of IV-L: 142, 102, 118, 169, 159, 128; IV-L-6 subterminal seta L 122.

Etymology - Named after Prof. Burkhard Scharf (Bremen, Germany), the collector of the mites described in this paper.

Remarks - The new species is similar to Limnesia vietnamensis Tuzovskij, 2013, described by Tuzovskij (2013a) on the basis of one female and one deutonymph from Vietnam. Both species have P-2 with a ventrodistal protrusion with a peg-like seta and a dorsum with the small posterior transverse platelet. Female L. vietnamensis differs from the new species in 1) separation between Ac-1 and Ac-2 considerably larger than half of diameter Ac-2, 2) peglike seta of P-2 longer and more slender, and (3) IV-L-6 with four short thick ventral setae (Tuzovskij 2013).

Distribution - Vietnam; known only from the locus typicus (Figure 25C).

Limnesia (Limnesia) cf. rimiformis Jin, 1997 (Figure 5)

Material examined - Vietnam, 15-43-1, ca. 35 $\mathrm{km} \mathrm{W}$ of Dà Nang, rice field, recently flooded, $16^{\circ} 16^{\prime} 02.2^{\prime \prime} \mathrm{N}, 107^{\circ} 51^{\prime} 52.2^{\prime \prime} \mathrm{E}$, alt. $10 \mathrm{~m}$ a.s.l., water depth $0.1 \mathrm{~m}$, substrate: loam covered by detritus, 1.v.2015, 1/0/0 (mounted).

Description - Male: Colour yellow-brownish; integument finely striated. Dorsum posteriorly with a small, rounded platelet (Figure 5A). Cx-I medially separated, medial margins well developed, apodemes short. Cxgl-4 separated from anterior and medial margin of Cx-III. Genital plate rounded, without anterior or posterior indentations, posterior margin convexly protruding; 5-10 small setae on genital plates, 3 of these located between Ac1 and Ac-2 (Figure 5B); Ac-2 and -3 closer to each other than Ac-1 and -2, separation Ac-1-2 as large as diameter of Ac-2; ejaculatory complex reduced to a spherical chamber with a pair of arms (Figure 5I). Excretory pore between associated glandularia.

Gnathosoma with slightly convex ventral margin and a long dorsodistal projections (Figure 5E);
P-2 ventral margin slightly bulging, peg-like seta not on a tubercle, inserted in the distal half; P-3 dorsally with three long setae; P-4 in anterior half ventrally with two long setae (proximal seta shorter than distal one), each associated with a tubercle, and more distally one small seta (Figures 5C-D).

Legs - Numbers of swimming setae: III-L-4, 6; III-L-5, 8; IV-L-4, 6; IV-L-5, 6; IV-L-6 bearing four stout ventral setae, and a long subterminal seta (Figure $5 \mathrm{~K})$, L ratio seta/IV-L-6; claws of I-III-L with dorsal and ventral clawlets (Figure 5G).

Measurements - Idiosoma L/W 756/644; posterior dorsal plate L/W 72/74, ratio 0.97; coxal field L/W 328/553; genital plate L/W 159/169, ratio 0.94; diameter Ac-1, 38-43; Ac-2, 31-33; Ac-3, 38-39. Gnathosoma vL 137; chelicera total L 217, claw L 69 , basal segment L 159, L basal segment/claw ratio 2.3. Palp: total L 320, dL/H, dL/H ratio: $\mathrm{P}-1,19 / 42$, 0.45; P-2, 92/62, 1.5; P-3, 69/54, 1.3; P-4, 106/32, 3.3; P-5, 34/15, 2.2; dL P-2/ 4 ratio 0.87. Legs: dL of I-L2-6: 53, 59, 69, 87, 100, 117; dL/H I-L-6 ratio 3.3; dL of IV-L: $117,85,111,155,155,151$; IV-L-6 subterminal seta L 79.

Remarks - Due to the similar shape of palp (peg-like ventral seta of P-2 inserted directly on the slightly convex segment surface) and genital field (genital plate rounded, without anterior and posterior indentations, posterior margin convexly protruding, separation between Ac-1 and Ac-2 less than half of diameter Ac-2) the single specimen from Vietnam shows general agreement with Limnesia rimiformis Jin, 1997 from China (Jin 1997). Following the original description of the latter species it differs by the dorsum without posterior platelet(s), a character lacking in descriptions of all other species of the genus from China (see Jin 1997). As it is possible that this character has been overlooked, we keep our specimen tentatively under L. rimiformis. 

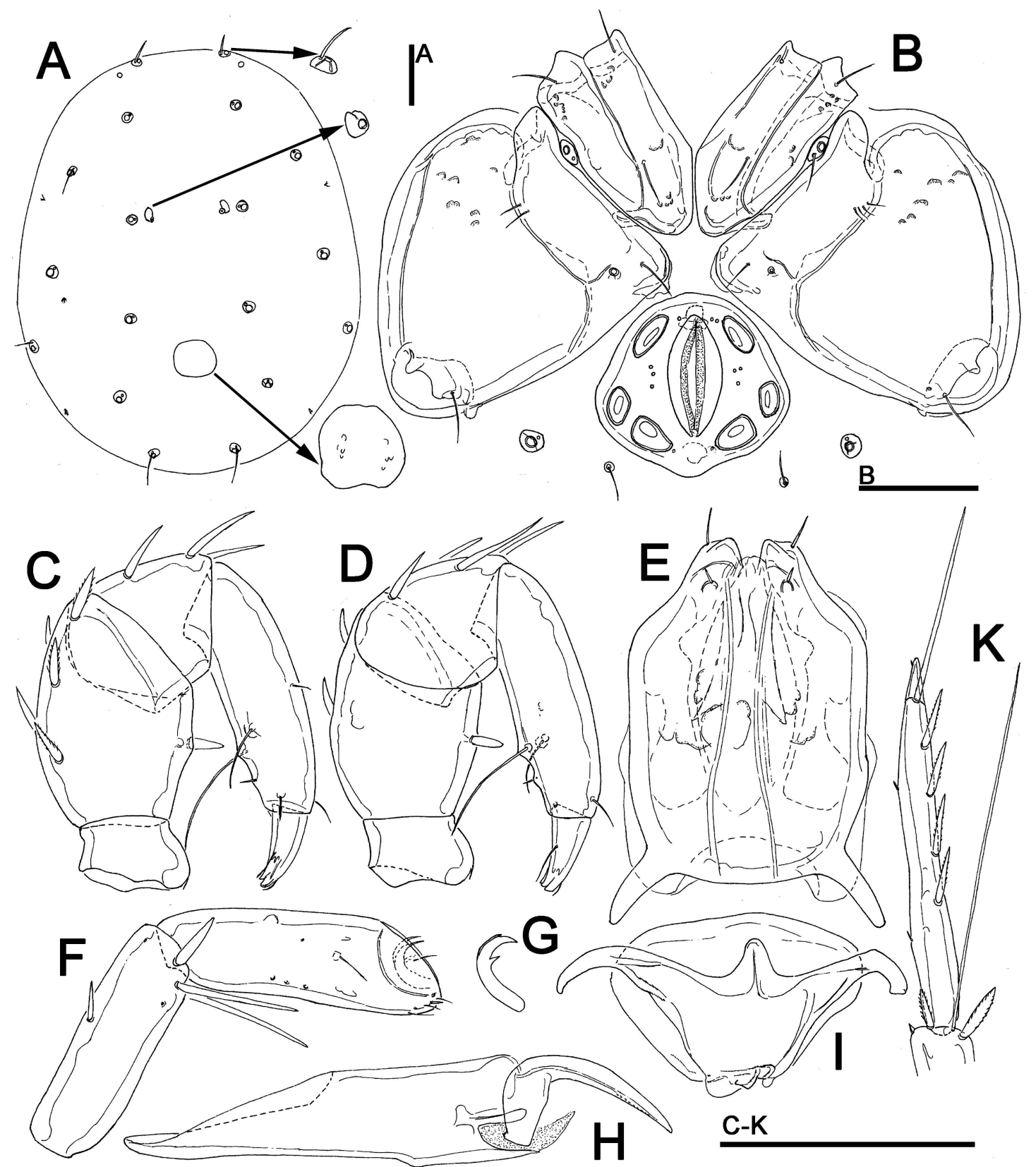

FIGURE 5: Limnesia (Limnesia) cf. rimiformis Jin, 1997, male, rice field W of Dà Nang, Vietnam: A - idiosoma, dorsal view; B - coxal and genital field; C - palp, lateral view; D - palp, medial view; E - gnathosoma; F - I-L-5 and -6; G - III-L claw; H - chelicera; I ejaculatory complex; K - IV-L-6. Scale bars $-100 \mu \mathrm{m}$. 


\section{Family Hygrobatidae Koch Genus Hygrobates Koch, 1837 Subgenus Hygrobates s. str.}

\section{Hygrobates (Hygrobates) hamatus K. Viets, 1935 (Figure 6)}

Material examined - Laos, 15-32-1, Kouangxi Waterfall, pond behind artificial barrier within a branch near the main brook, $19^{\circ} 44^{\prime} 56^{\prime \prime} \mathrm{N}$, $101^{\circ} 59^{\prime} 33^{\prime \prime E}$, alt. c. $490 \mathrm{~m}$ a.s.l., water depth 0.4 $\mathrm{m}$, substrate: travertine mud covered by a thick layer of leaves, 21.iv.2015, 0/1/0 (mounted).

Morphology - Female: Integument striated; posteromedial margin of Cx-I straight; apodemes of CX-II forming an acute angle; Cx-IV subtriangular in shape, with anterior and posterior margins converging to median line, posteromedial margin with a well protruding apodeme (Figure 6A). Acetabula in in a triangular arrangement, medial margin of genital plate indented in the centre. P-2 ventral margin weakly concave, distally forming a right angle, denticles covering distal $2 / 3$ of P-3 ventral margins, P-4 ventral setae on the same level (Figure 6C). Swimming hairs absent.

Measurements - Idiosoma L/W 844/638; genital field L/W 153/187, genital plate L 114 - 116. Palp: total $\mathrm{L} 427, \mathrm{dL} / \mathrm{H}, \mathrm{dL} / \mathrm{H}$ ratio: $\mathrm{P}-1,23 / 35$, 0.67; P-2, 118/73, 1.62; P-3, 95/69, 1.39; P-4, 155/28, 5.5; P-5, 36/12, 3.1; L ratio P-2/P-4, 0.76. Legs: $\mathrm{dL}$ of I-L: $63,103,133,173,178,159$; dL of IV-L: 166, 150, 221, 266, 311, 241.

Remarks - The single female from Vietnam fits the original description of Hygrobates hamatus K. Viets, 1935 from Sumatra and Java (Viets 1935), but it is noticeable larger.

Distribution - A widespread species, known from India to Australia.

\section{Hygrobates (Hygrobates) henni Wiles, 2004} (Figure 7)

Material examined - Laos, 15-32-1, Kouangxi Waterfall, pond behind a artificial barrier within a branch near the main brook, $19^{\circ} 44^{\prime} 56^{\prime \prime} \mathrm{N}$, $101^{\circ} 59^{\prime} 33^{\prime \prime E}$, alt. c. $490 \mathrm{~m}$ a.s.l., water depth 0.4 $\mathrm{m}$, substrate: travertine mud covered by a thick layer of leaves, 21.iv.2015, 1/0/0 (mounted).

Morphology - Male: Integument papillate (Figure 7B). Posteromedial margin of Cx-I broadly rounded. Cx-IV with a distinct nose-like protruding medial margin. Genital plate anterior margin with a small knob-shaped medial projection projecting in a deep indentation, posterior margin deeply indented with a small protrusion in the centre of indentation; acetabula in a triangular arrangement, Ac-2 and Ac3 on the same level (Figure 7A). P-2 ventral margin proximally almost straight, distoventrally protruding in a long and slender projection, apically covered by a few small denticles; P-3 distally with 78 larger denticles covering more than half of ventral margin (Figures 7E-F); P-4 slender, ventral setae close to each other (separation $22 \mu \mathrm{m}$ ).

Measurements - Idiosoma L/W 713/637; coxal field L/W 331/522, Cx-III W 406; genital plate L/W 166/213, ratio 0.78 ; ejaculatory complex L 132. Palp: total L 378, dL/H, dL/H ratio: P-1, 30/36, 0.83; P2, 97/65, 1.5; P-3, 77/57, 1.35; P-4, 126/31, 4.1; P5, 48/16, 2.9; L ratio P-2/P-4, 0.77; chelicera total L 254, claw L 90, basal segment L 170, L basal segment/claw ratio 1.9. Legs: dL of I-L-5-6 (Figure 7C): 135, 130; dL of IV-L: 113, 94, 131, 194, 213, 163.

Remarks - The single male from Kauangxi Waterfall matches the general morphology of Hygrobates henni Wiles, 2004. This species was described by Wiles (2004) from Mai Yim waterfalls in Thailand.

Distribution - Previously known only from Thailand, and here reported for the first time for Laos.

\section{Hygrobates (Hygrobates) cf. sinensis Uchida \& Imamura, 1951 (Figure 8)}

Material examined - Vietnam, 15-51-1, Mekong delta at Can Tho, Mekong river, shore, near ferry landing place, $10^{\circ} 03^{\prime} 43^{\prime \prime} \mathrm{N}, 105^{\circ} 47^{\prime} 02^{\prime \prime} \mathrm{E}$, alt. 1 $\mathrm{m}$ a.s.l., water depth $0.2-0.5 \mathrm{~m}$, substrate: greyblack sand, Eichhornia crassipes, 7.v.2015, 0/1/0 (mounted). 
Pešić V. and Smit H.

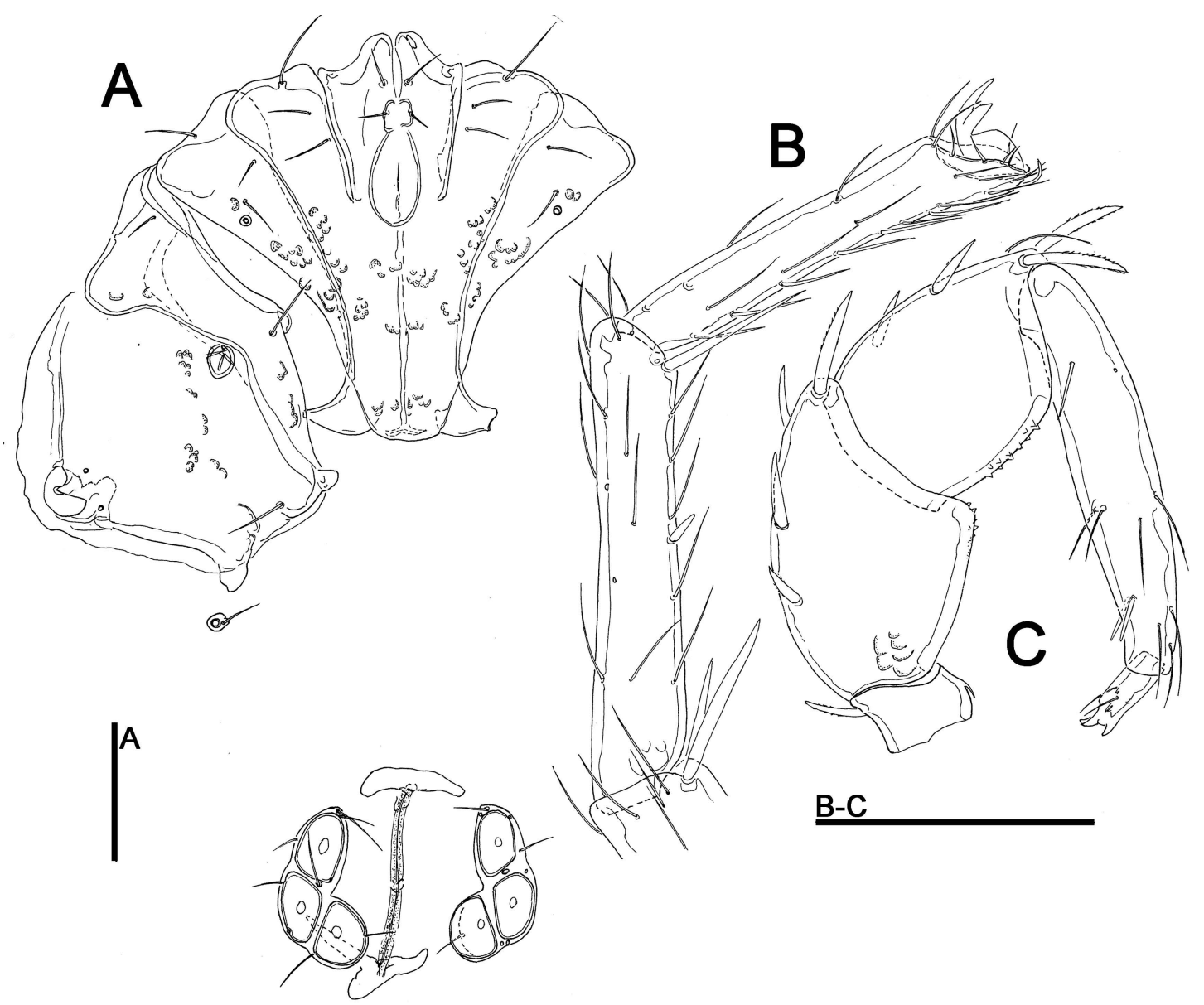

FIGURE 6: Hygrobates (Hygrobates) hamatus K. Viets, 1935, male, Kauangxi Waterfall, Laos: A - coxal and genital field; B - I-L-5 and -6; C - palp. Scale bars $-100 \mu \mathrm{m}$. 

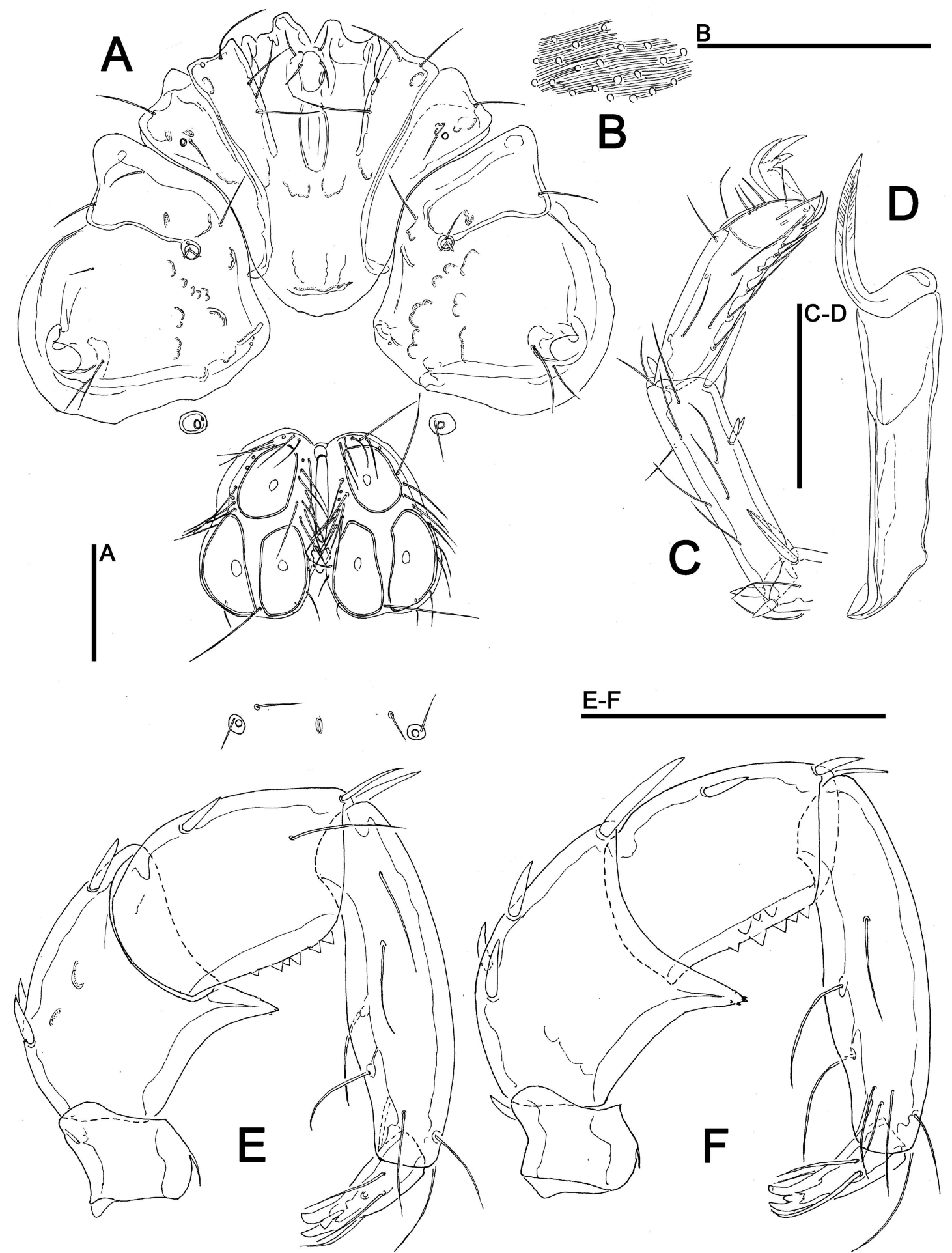

FIGURE 7: Hygrobates (Hygrobates) henni Wiles, 2004, male, Kauangxi Waterfall, Laos: A - idiosoma, ventral view; B - details of dorsal integument; C - I-L-5 and -6; D - chelicera; E-F - palp. Scale bars - $100 \mu \mathrm{m}$. 
Pešić V. and Smit H.

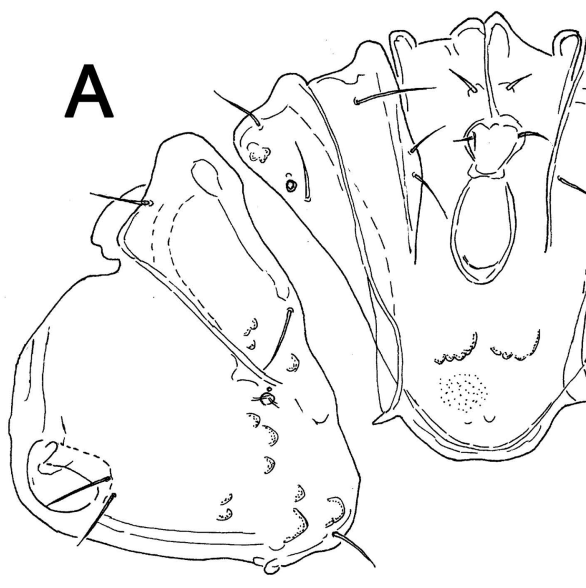

(0)
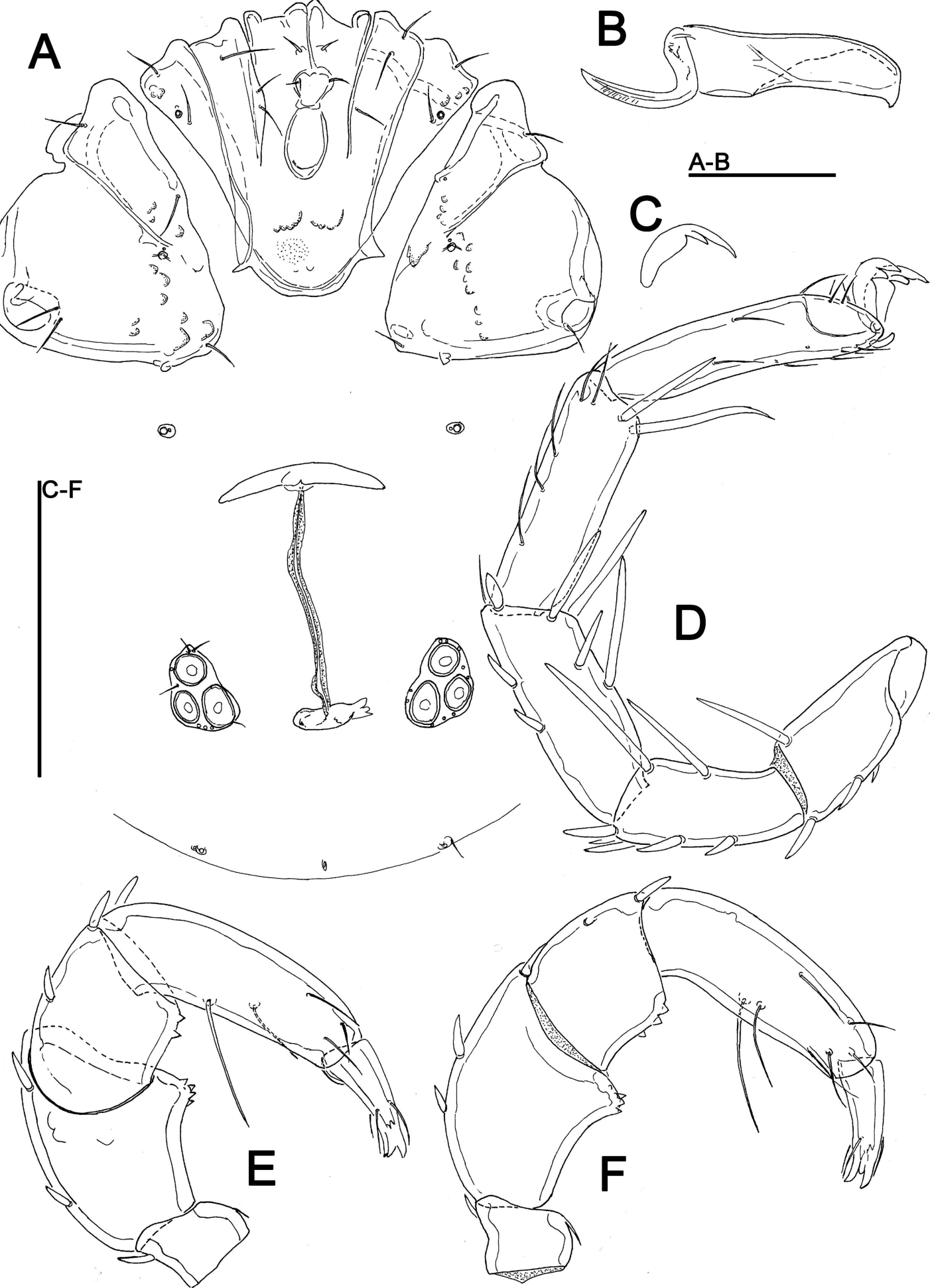

FIGURE 8: Hygrobates (Hygrobates) cf. sinensis Uchida \& Imamura, 1951, female, Mekong River, Vietnam: A - idiosoma, ventral view; B chelicera; C - III-L claw; D - I-L-2-6; E-F - palp. Scale bars - $100 \mu \mathrm{m}$. 
Morphology - Female: Integument finely striated. Posteromedial margin of Cx-I slightly concave; Cx-IV subtriangular in shape, with anterior and posterior margins converging to median line. Gonopore very long, genital plates short, restricted to the level of postgenital sclerite, acetabula in triangular position (Figure 8A). P-2 ventral margin concave, distally protruding in a slightly knob-shaped projection covered by large, scattered denticles; P-3 with a few large and scattered ventral denticles in the distal part (Figures 8E-F); P-4 ventral setae separation $14 \mu \mathrm{m}$. Swimming hairs absent.

Measurements -Idiosoma L 610; coxal field: L 252, Cx-III W 334, Cx-I+II mL 194; genital field L/W 185/209, genital plate L/W 62-63/41, gonopore L 163. Palp: total $\mathrm{L} 298, \mathrm{dL} / \mathrm{H}, \mathrm{dL} / \mathrm{H}$ ratio: $\mathrm{P}-1$, 24/29, 0.84; P-2, 85/51, 1.67; P-3, 51/45, 1.14; P-4, 94/31, 3.1; P-5, 44/15, 2.9; L ratio P-2/P-4, 0.9; chelicera total L 220. Legs: dL of I-L-2-6: 71, 65, 85, 89, 101; dL of IV-L: 88, 68, 105, 149, 155, 158.

Remarks - The single female from Vietnam matches the general morphology of Hygrobates sinensis Uchida \& Imamura, 1951 from China. However, only a single female was taken, so our record should be considered tentative until males are examined.

Distribution - China, Vietnam.

\section{Genus Vietnobates n. gen}

Diagnosis - Character states of family Hygrobatidae (see Cook 1974). Dorsum and posterior venter without sclerotized muscle attachment plates. Coxae in four groups; Cx-I separated medially. Gnathosoma with a posterior anchoral process extending beyond posterior end of Cx-I+II. Glandular opening on Cx-IV near suture line of Cx-III/IV. CxIV posteromedial margin with short posterior projections, apodemes extending anteriorly from these projections not extending to Cxgl-IV. Genital field with three pairs of acetabula. P-2 without a ventral projection and ventral margin without denticles; P4 lacking a medial sword seta and a dense dorsodistal setation, P-4 ventral setae at the same level, in distal third of segment. I-L-5 at distal end with a pair of thickened, pointed setae, I-L-6 not curved.
Type species - Vietnobates oryzae $\mathbf{n}$. sp.

Etymology - The genus name is derived from the country of the type locality.

Remarks - The new genus resembles a number of Australiobates-like genera from Australia in the elongated anchoral process, e.g., Australiobates Lundblad, 1941, Coaustraliobates Cook, 1974, Pseudoaustraliobates Smit, 2009. Not any of these genera are known from the Oriental region. The combination of the following characters 1) gnathosoma with a posterior anchoral process exceeding posterior end of Cx-I+II, 2) Cx-IV posteromedial margin with short projections, apodemes extending anteriorly from these projections not extending to Cxgl4 , 3) P-4 ventral setae at the same level, in distal third, medial sword seta absent, and 4) I-L-5 at distal end with a pair of thickened, pointed setae, separates the new genus from all other Australiobateslike mites.

Vietnobates oryzae n. sp. (Figure 9)

Type material - Holotype female, dissected and slide mounted, Vietnam, 15-48-1, dam, ca. $35 \mathrm{~km}$ NW of Da Nang, $16^{\circ} 14^{\prime} 55.9^{\prime \prime} \mathrm{N}, 107^{\circ} 47^{\prime} 31.0^{\prime \prime} \mathrm{E}$, alt. 38 $\mathrm{m}$ a.s.l., water depth $0.4 \mathrm{~m}$, substrate: stones, gravel, between fresh and rotted leaves, 4.v.2015.

Diagnosis - (Male unknown). As for genus.

Description - Female: Integument striated; apodemes of Cx-II directed more posteriorly, CxIV posteromedial margin with a slightly protruding apodeme. Genital field with acetabula subtriangular in shape, in an obtuse triangle; excretory pore smooth, Vgl-1 separated from Vgl-2. P-2 ventral margin straight, distally forming a right angle, P-3 ventral margin straight or slightly concave; $\mathrm{P}-4$ ventral setae at the same level (Figures 9B-C). Basal segment of chelicera dorsally with a pointed projection (Figure 9E). I-L-5 at distal end with a pair of thickened and pointed setae (Figure 9D); I-L-6 straight; leg claws with a well developed claw blade with dorsal and ventral clawlets (Figure 9F); III-L-5 with two and IV-L-5 with 3 swimming hairs, IV-L-6 with two long bristles.

Measurements - Idiosoma L/W 1110/820; coxal field L/W 353/605; Cx-III W 453; genital field 
Pešić V. and Smit H.

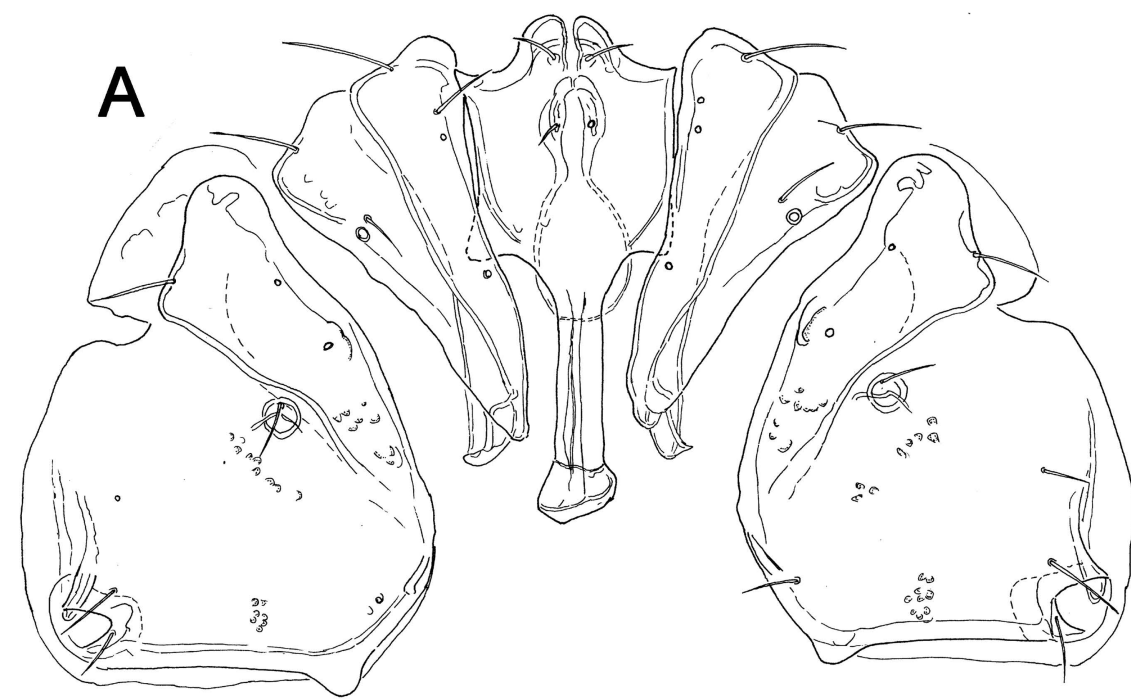

(6)

(0)

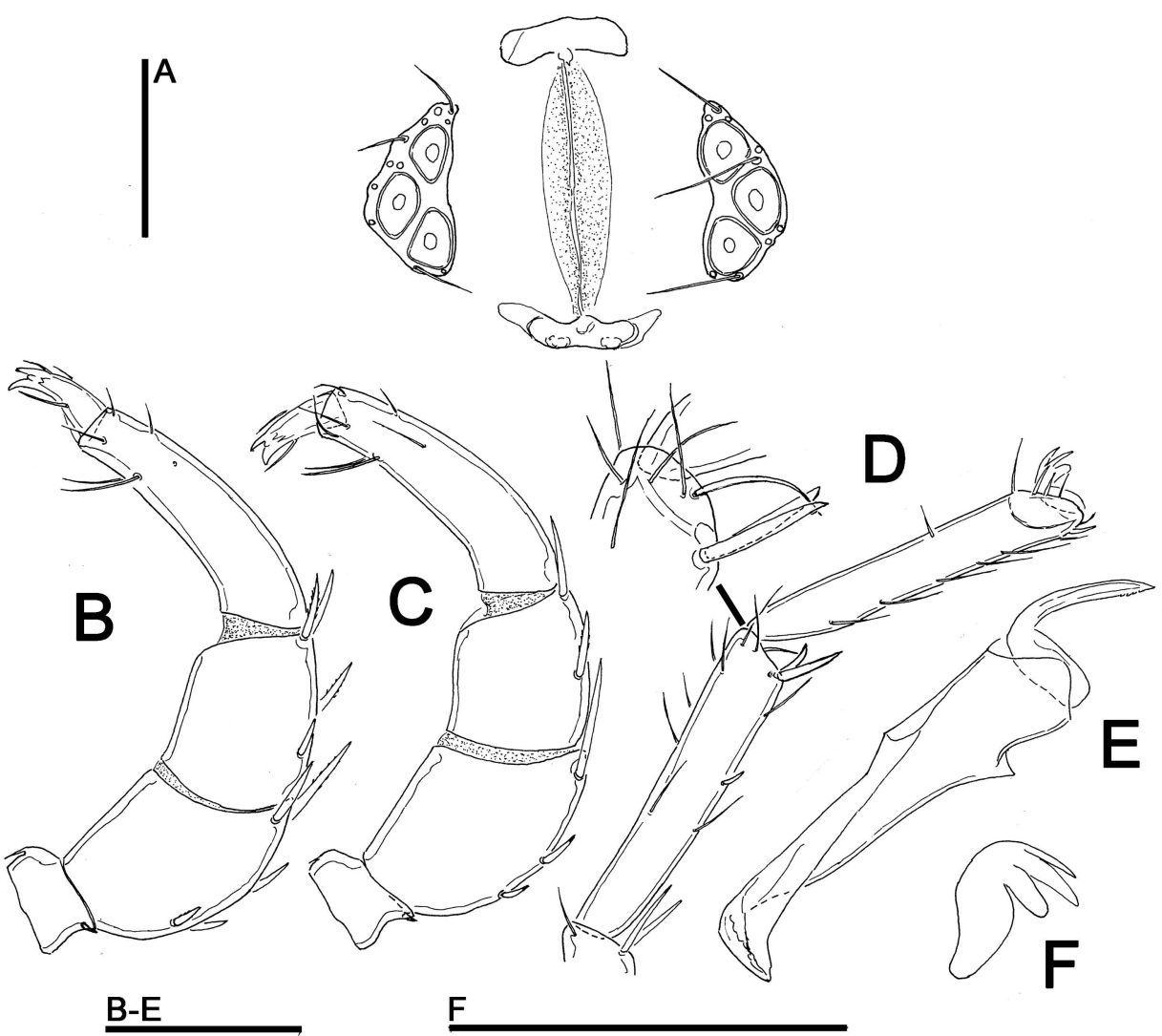

FIGURE 9: Vietnobates oryzae n. sp., female, dam NW of Da Nang, Vietnam: A - coxal and genital field; B-C - palp; D - I-L-5 and -6 (inset: distal part of I-L-5); E - chelicera; F - III-L claw. Scale bars - $100 \mu \mathrm{m}$. 
L/W 188/241, genital plate L/W 100 - 103/44 47 , gonopore L 163 , pregenital sclerite $\mathrm{W} 72$, postgenital sclerite $W$ 93; egg maximum diameter $(n-3)$ 147-156. Palp: total $\mathrm{L} 448, \mathrm{dL} / \mathrm{H}, \mathrm{dL} / \mathrm{H}$ ratio: $\mathrm{P}-$ 1, 31/48, 0.64; P-2, 125/78, 1.6; P-3, 86/68, 1.27; P4, 155/43, 3.6; P-5, 51/23, 2.2; L ratio P-2/P-4, 0.8; gnathosoma vL 131, with apodemes 278; chelicera total L 141, claw L 40, basal segment L 105, L basal segment/claw ratio 2.6. Legs: dL of I-L-2-5: 94, 125, 161, 178, 183; dL of IV-L: 150, 119, 169, 236, 228, 209.

Etymology - The name of the new species refers to the rice (- Latin oryza) field where the new species was found.

Distribution - Vietnam; known from the locus typicus only.

\section{Family Unionicolidae Oudemans, 1909 \\ Subfamily Pionatacinae K. Viets, 1916 \\ Genus Neumania Lebert, 1879}

\section{Neumania (Neumania) ambigua Piersig, 1906}

Material examined - Cambodia, 15-35-1, Angkor, moat around the main Angkor temple, $13^{\circ} 24^{\prime} 54.0^{\prime \prime} \mathrm{N}, 103^{\circ} 51^{\prime} 34.8^{\prime \prime} \mathrm{E}$, alt. $26 \mathrm{~m}$ a.s.l., depth 0.4-0.2 $\mathrm{m}$, substrate: red sand covered by detritus, 23.iv.2015, 8/6/0 (mounted).

Distribution - India, Indonesia, Singapore, Japan, Thailand, Philippines, Japan, Australia and eastern Siberia.

\section{Subfamily Unionicolinae Oudemans, 1909 Genus Unionicola Haldeman, 1842 Subgenus Majumderatax Vidrine, 1993 \\ Unionicola (Majumderatax) sp. (Figure 10)}

Material examined - Vietnam, 15-51-1 Mekong delta at Can Tho, Mekong River, shore, near ferry landing place, $10^{\circ} 03^{\prime} 43^{\prime \prime} \mathrm{N}, 105^{\circ} 47^{\prime} 02^{\prime \prime} \mathrm{E}$, alt. $1 \mathrm{~m}$ a.s.l., water depth $0.2-0.5 \mathrm{~m}$, substrate: grey-black sand, Eichhornia crassipes, 0/0/1 (mounted).

Morphology - Deutonymph: P-2 with one serrate seta in ventral and proximomedial position; $\mathrm{P}$ 4 with strongly developed cone-shaped, projections on ventral margin, two proximal, apically bearing a denticle-like seta, one distal, apically bearing a peglike seta; P-5 claw bifurcated into two very long, slender clawlets (length: dorsal 32, ventral $25 \mu \mathrm{m}$ ) (Figures 10B-C). Provisional genital field with two pairs of acetabula (Figure 10A). I-L-5 with a large (L $55 \mu \mathrm{m}$ ) blade-like distoventral seta (Figure 10D).

Measurements - Idiosoma L/W 447/378; coxal field L/W 225/252; provisional genital plate L/W 37/26, Ac diameter 19-20. Palp: total L 196, dL/H, $\mathrm{dL} / \mathrm{H}$ ratio: $\mathrm{P}-1,12 / 25,0.5 ; \mathrm{P}-2,60 / 35,1.7 ; \mathrm{P}-3$, 19/34, 0.55; P-4, 65/28, 2.3; P-5, 40/-; dL ratio P2/P-4, 0.93; gnathosoma vL 95; chelicera total L 97.

Remarks - In addition to the type species, Unionicola hankoi Szalay, 1927, known from the Palaearctic, the subgenus includes Unionicola crenipalpis Lundblad, 1969 from Burma. The combination of a well developed cone-shaped, projections on ventral margin of P-4 (absent in U. crenipalpis) and one proximomedial serrate seta on P-2 (lacking in $U$. hankoi), easily separates the single deutonymph from the Mekong delta from all other species of the subgenus Majumderatax. Most probably we are dealing with an undescribed species, but since adults are not available, a final decision can not be made.

\section{Family Pionidae Thor, 1900 Genus Schwoerbelia n. gen.}

Diagnosis - Female (Male unknown): Character states of family Pionidae (see Cook 1974). Dorsum soft. All coxal setae slender, not spatulate; medial margin of Cx-III almost as long as medial margin of $\mathrm{Cx}-\mathrm{IV}$, posterior margin of $\mathrm{Cx}-\mathrm{IV}$ concave, without angular projections. Genital bay very shallow, gonopore very long, genital plates broad and rounded, much smaller than gonopore, with 5 pairs of acetabula. P-3 with a very long lateral seta, P-4 with a peg-like mediodistal seta, ventral setae not associated with tubercles (Figures 11B-C); gnathosoma with posterior anchoral process. Legs slender, swimming setae present.

Type species - Schwoerbelia pioniformis $\mathbf{n}$. sp.

Etymology - The genus name is in honour of Jürgen Schwoerbel (1930-2002), who described one of the pionid subfamilies. Moreover, he was one of 

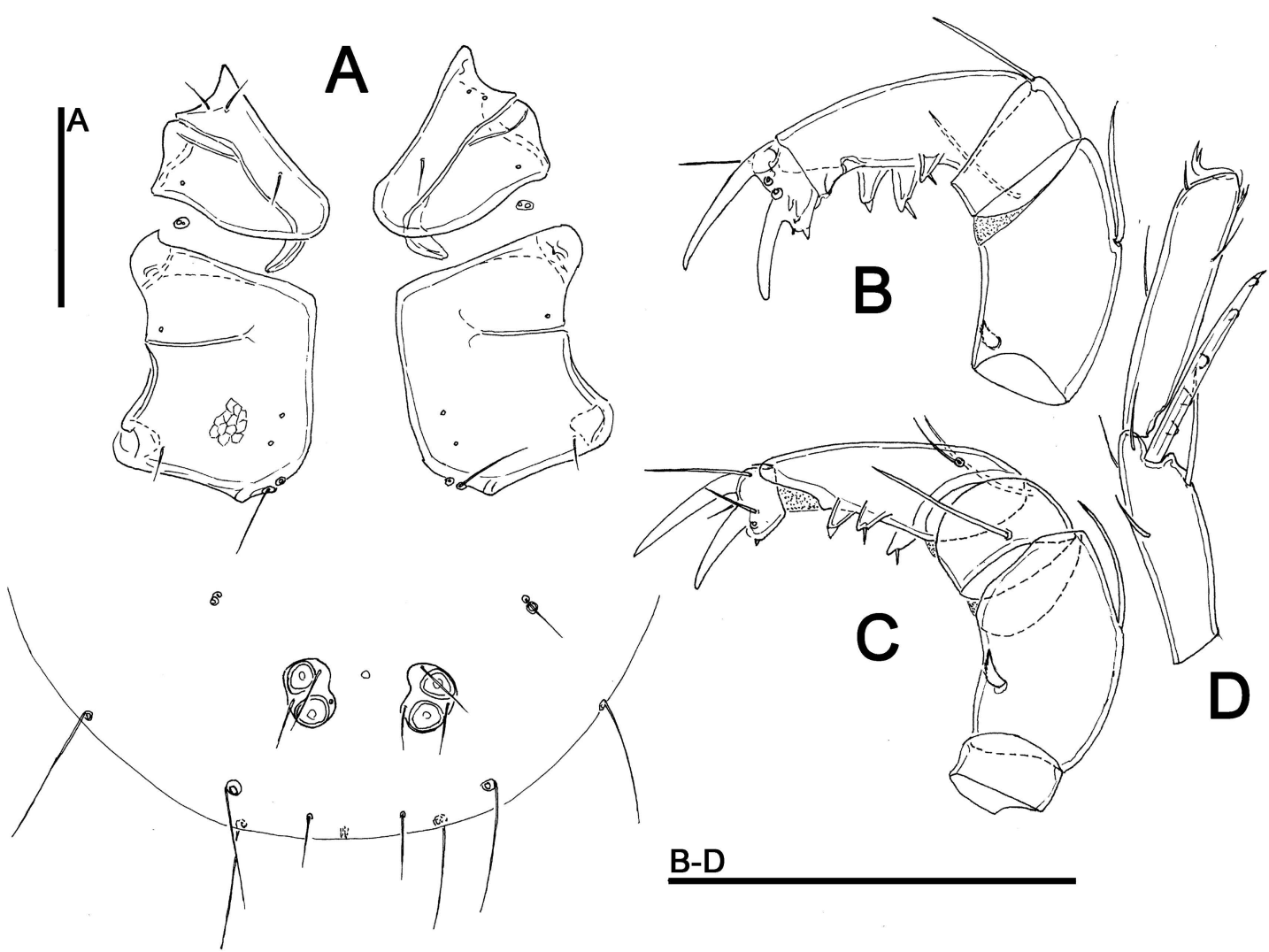

FIGURE 10: Unionicola (Majumderatax) sp., deutonymph, Mekong River, Vietnam: A - idiosoma, ventral view; B-C - palp; D - I-L-5 and -6. Scale bars $-100 \mu \mathrm{m}$.

the editors of a new standard work on European water mites, published in the series "Süßwasserfauna von Mitteleuropa".

Remarks - Due to the following characters: medial margin of posterior coxal plates formed jointly by $\mathrm{Cx}$-III and $\mathrm{Cx}-\mathrm{IV}$, all setae on Cx-II and -III fine, not thickened, gnathosoma ventral margin posteriorly projecting in an anchoral process (in ventral view bifurcate as in Figure 11D), and P-4 with a distoventral peg-like seta, the female of new species resembles to those of genus Piona. However the single female from a stream in Vietnam is unique in P3 with a very long lateral seta, exceeding the tip of P-5. In all known members of subfamily Pioninae Thor lateral setae on P-3 are short. The new genus resembles Huitfeldtiinae (P-3 with a very long lateral seta) which in addition to Huitfeldtia Thor, 1900 (Holarctic), includes Larri Harvey, 1996 (Australia) and Gereckea Smith \& Cook, 2009 (Canada). The new genus differs in slender, not spatulate coxal setae (present in Huitfeldtia), posterior margin concave, without acute-angled apodemes, and a small peg, not a prominent spine-like mediodistal seta on P-4 (see Smith et al. 2015). In most pionid groups, characters (sexual dimorphism on leg segments) important for classification are restricted to males. However the unique features of female from Vietnam are large enough to warrant the erection of the new genus.

\section{Schwoerbelia pioniformis $\mathbf{n}$. sp. (Figure 11)}

Type material - Holotype female, dissected and slide mounted, Vietnam, 15-44-1 Bach Má National Park, brook with a pool behind a natural barrier, $16^{\circ} 11^{\prime} 15.5^{\prime \prime} \mathrm{N}, 105^{\circ} 50^{\prime} 54.7^{\prime \prime} \mathrm{E}$, alt. $1130 \mathrm{~m}$ a.s.l., water depth $0.2 \mathrm{~m}$, substrate: leaves in a lentic bay, 2.v.2015. 


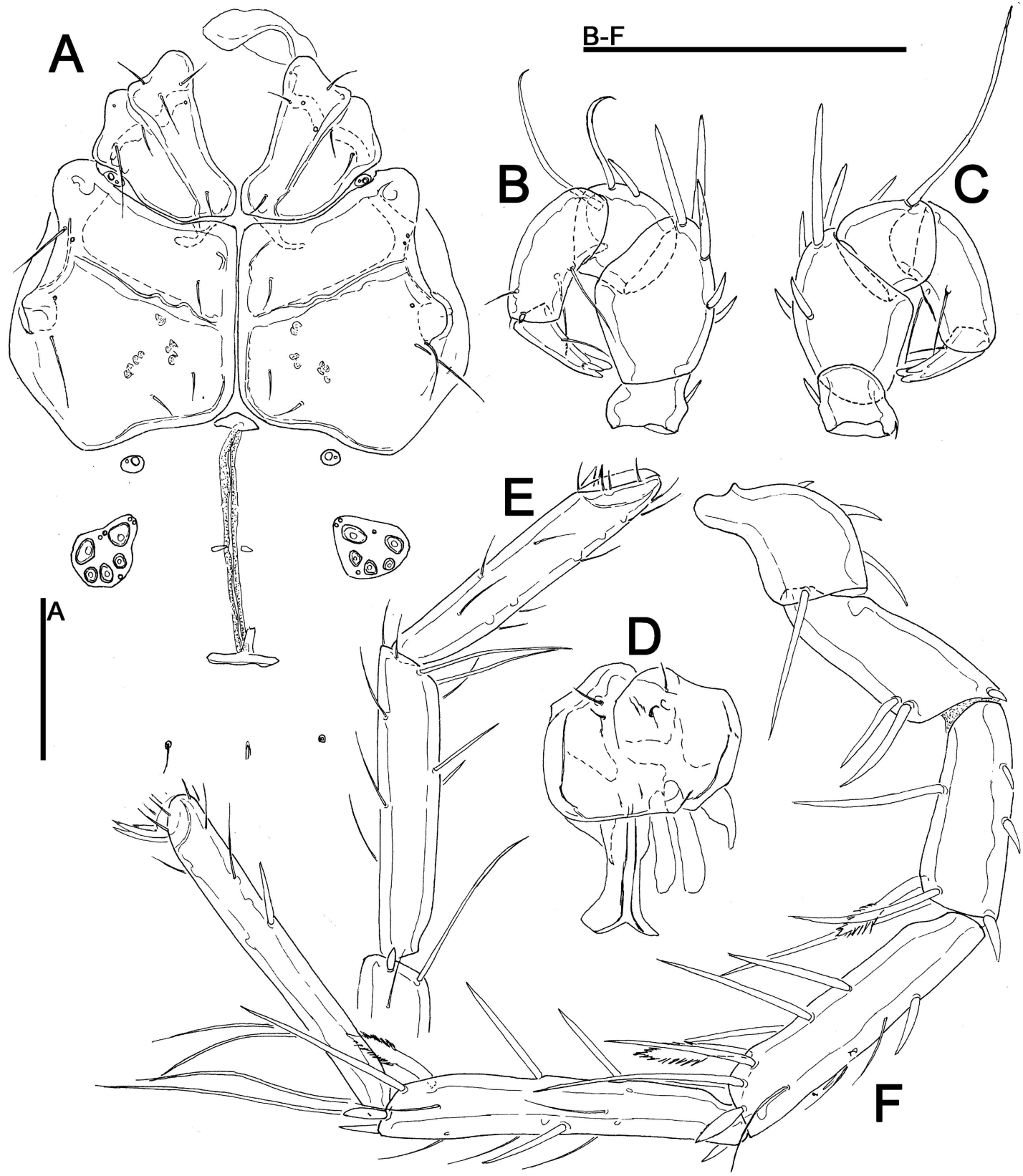

FIGURE 11: Schwoerbelia pioniformis n. gen., n. sp., female, Bach Má National Park, Vietnam: A - idiosoma, ventral view; B-C - palp; D gnathosoma; E - I-L-5 and -6; F - IV-L. Scale bars - $100 \mu \mathrm{m}$. 
Diagnosis - (Male unknown). As for genus.

Description - Dorsum soft. All coxal setae slender; medial margin of Cx-III almost as long as medial margin of Cx-IV. Genital bay very shallow, gonopore very long, genital plates broad and rounded, with 5 pairs of small acetabula arranged along the plate margins, medial margin straight or slightly concave, pregenital sclerite small, triangular (Figure 11A); excretory pore smooth. P-3 with a very long lateral seta, P-4 with two long setae close to each other, and a peg-like mediodistal seta (Figures 11B-C); P-5 long (around $80 \%$ L of P-4); gnathosoma with posterior anchoral process. Legs: number of swimming setae: I-L-1, 1 (short); II-L-4, 2; II-L-5, 2-3; III-L-4, 3; III-L-5, 3; IV-L-4, 3; IV-L-5, 3-4; IV-L-3-5 each with one strong ventrodistal pennate seta (Figure 11F).

Measurements - Idiosoma L/W 638/538; coxal field L/W 253/291; genital field L/W 165/214; genital plate L/W 51-52/38; gonopore L 148, pregenital sclerite $\mathrm{W} 29$. Palp: total $\mathrm{L} 179, \mathrm{dL} / \mathrm{H}, \mathrm{dL} / \mathrm{H}$ ratio: P-1, 19/25, 0.75; P-2, 49/39, 1.28; P-3, 31/30, 1.05; P4, 48/22, 2.2; P-5, 32/12, 2.6; dL ratio P-2/P-4, 1.03; gnathosoma vL 49 , with anchoral process 85 ; chelicera total L 75. Legs: dL of I-L: 41, 48, 66, 91, 98, 103; dL of IV-L: 52, 55, 68, 97, 115, 119.

Etymology - The name of the new species refers to its resemblance with Piona species.

Distribution - Vietnam; known only from the locus typicus (Figure 25C).

\section{Subfamily Foreliinae Thor, 1923 Genus Forelia Haller, 1882}

\section{Forelia (Forelia) gereckei n. sp. (Figure 12)}

Type material - Holotype female, dissected and slide mounted, Laos, 15-32-1, Kouangxi Waterfall, pond behind a artificial barrier within a branch near the main brook, $19^{\circ} 44^{\prime} 56 " \mathrm{~N}, 101^{\circ} 59^{\prime} 33^{\prime \prime} \mathrm{E}$, alt. ca. 490 $\mathrm{m}$ a.s.l., water depth $0.4 \mathrm{~m}$, substrate: travertine mud covered by a thick layer of leaves, 21.iv.2015. Paratypes: 0/2/0, same data as holotype.

Diagnosis - (Male unknown). Anterior margin of idiosoma medially concave; genital plates with
13-16 pairs of acetabula; ventral margin of P-4 without setal tubercles, with setae located close to each and a blunt, peg-like mediodistal setal; leg claw and clawlet blunt.

Description - Female: Colour yellow with brown markings; anterior margin of idiosoma medially concave or straight, dorsum with three pairs of platelets, anterior platelets oblong, central platelets slightly more lateral and irregularly rounded, posterior platelets small, close to each other (Figure 12A). Genital plates slightly extended anteriorly with 13-16 pairs of acetabula, medial margin straight or slightly concave, pregenital sclerite large; excretory pore on platelet. P-4 stocky, ventral margin of $\mathrm{P}-4$ with setae located close to each other, without setal tubercles (Figures 12C-D), distal margin with a short blunt seta; P-5 around 70 $\% \mathrm{~L}$ of P-4. Legs: number of swimming hairs: II-L4, 3; II-L-5, 4; III-L-4, 4; III-L-5, 6; IV-L-4, 3; IV-L-5, 5; claws of I-L large, claw and clawlet blunt.

Measurements — Idiosoma L/W 709/530; coxal field L/W 267/400; genital plate L/W 109-113/78; gonopore L 134, pregenital sclerite W 78; egg maximum diameter $(\mathrm{n}-2)$ 147. Palp: total $\mathrm{L} 236, \mathrm{dL} / \mathrm{H}$, $\mathrm{dL} / \mathrm{H}$ ratio: P-1, 27/34, 0.78; P-2, 69/41, 1.68; P-3, 37/33, 1.12; P-4, 60/25, 2.4; P-5, 43/19, 2.3; dL ratio P-2/P-4, 1.15; gnathosoma (with posterior anchoral process) vL 93; chelicera total L 122, claw L 38, basal segment L 84, L basal segment/claw ratio 2.2. Legs: dL of I-L: 45, 43, 55, 61, 66, 89; dL/H I-L-6 ratio 2.8.

Etymology - Named after Reinhard Gerecke (Tübingen) in appreciation of his studies of water mites.

Remarks - Due to the similar morphology of the dorsum (three pairs of platelets), genital plates (medial margin extended anteriorly) and palp (P4 without setal tubercles) the specimens from Laos resemble Forelia flexipoda Jin, 1995 from Guizhou, China. The latter species differs in larger dimensions of idiosoma and palps, medially projecting anterior margin of idiosoma, a very small mediodistal peg-like seta of P-4, claws of I-L pointed (Jin 1999: figure 9) and in the increased number of acetabula (26-27 pairs, from Jin 1995).

Distribution - Laos; known only from the locus typicus (Figure 25B). 

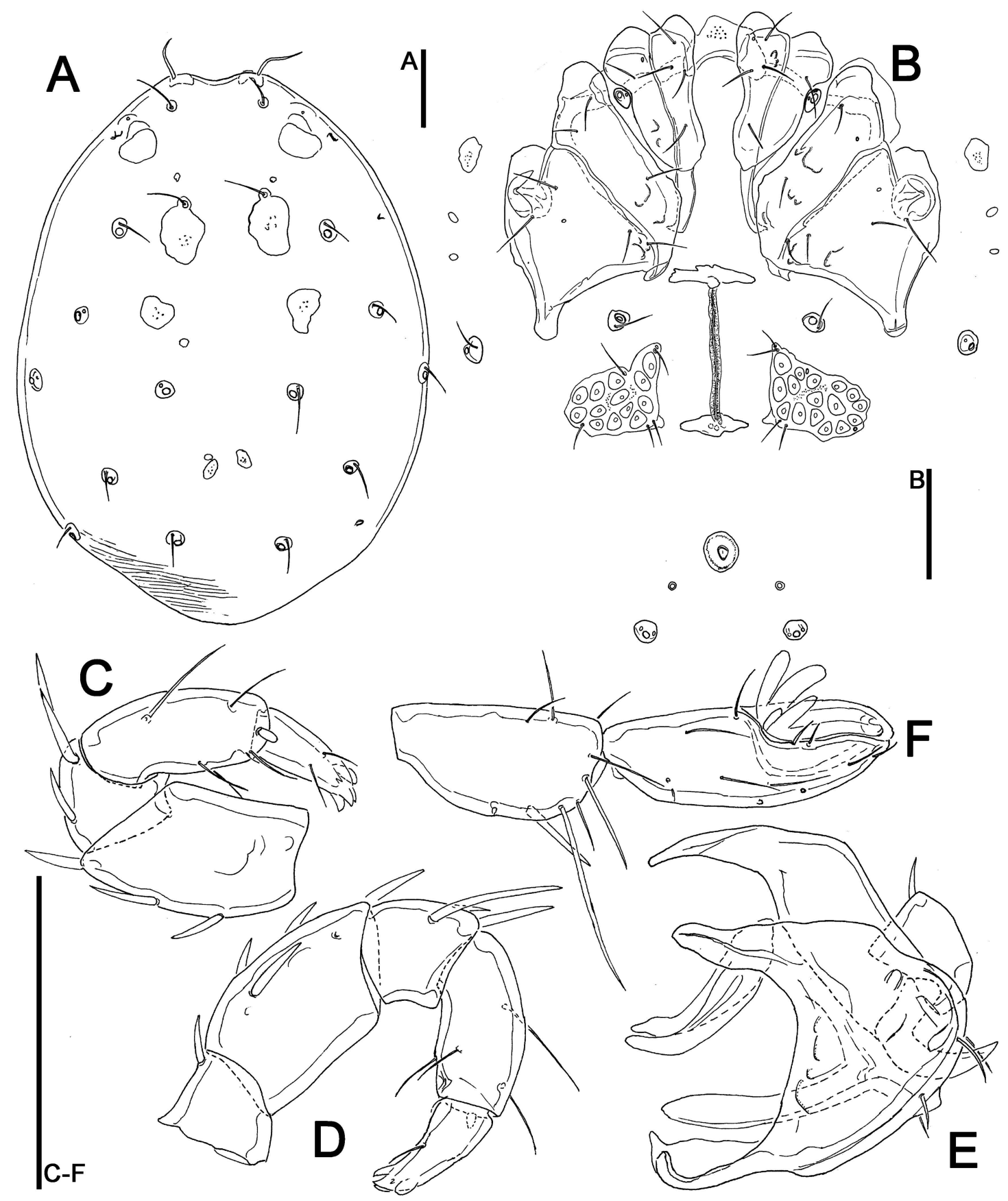

FIGURE 12: Forelia (Forelia) gereckei n. sp., female, Kauangxi Waterfall, Laos: A - idiosoma, dorsal view; B - idiosoma, ventral view; C palp (P-1 lacking); D - palp; E - gnathosoma and chelicera, lateral view; G - I-L-5 and -6. Scale bars - $100 \mu \mathrm{m}$. 
Family Aturidae Thor, 1900

Subfamily Axonopsinae K. Viets, 1929

Genus Hexaxonopsis K. Viets, 1926

Subgenus Hexaxonopsis s. str.

\section{Hexaxonopsis laosensis n. sp. (Figures 13-14, 15A-B)}

Type material - Holotype male, dissected and slide mounted, Laos, 15-33-1, Kouangxi Waterfall, lentic bay within a pond behind a travertine barrier within the main brook, $19^{\circ} 44^{\prime} 55.9^{\prime \prime} \mathrm{N}, 101^{\circ} 59^{\prime} 33.4^{\prime \prime} \mathrm{E}$, alt. ca. $490 \mathrm{~m}$ a.s.l., water depth $0.5 \mathrm{~m}$, substrate: travertine mud covered by some leaves. Paratypes: $4 / 5 / 0$, same data as holotype, one female dissected and slide mounted.

Diagnosis - Dorsal shield colour pattern consisting of a light-reddish elongated central patch; lateral margins posterior to IV-L insertions with developed triangular projection on each side of ventral shield.

Description - Dorsal and ventral shields anteriorly lightly fused; dorsal shield with seven pairs of glandularia (the seventh pair inconspicuous, flanking the excretory pore); postocularia well distanced from anterior margin; excretory pore projecting, located at the posterior end of dorsal shield; anterior portion of dorsal shield with 14-15 pairs of triangular, posteriorly-directed (hyaline?) denticles (Figures 13A,14A); dorsal shield colour as shown in Figures 15A-B; eye pigment well developed. Ventral shield oval, slightly truncate at anterior end, lateral margins rounded, with well developed triangular projection on each side (Figures 13B,14B), posterior to the insertions of IV-L. Lateral margins of Cx-I/II with 1-3 strong, hook-like, posteriorly-directed projections; two pairs of glandularia in region between genital field and opening for insertion of IV-L, these relatively close together; a relatively long longitudinal ridge posterior to IV-L insertions. Genital field with three pairs of Ac, arranged in an arc. Palp: ventral margin of P-2 convex, distal margin of P3 with well developed hyaline extensions, ventral margin of P-4 convexly protruding in the centre, here with two seta (one long and heavy, another long and slender) on small elevated ridges (Figures 13C-D,14C). Legs: number of swimming setae: II-
L-4, 1; II-L-5, 2-3; III-L-4, 2; III-L-5, 2-3; IV-L-4, 2; IV-L-5, 3. Female: Gonopore relatively large (Figure 14B).

Measurements - Male: Dorsal shield L/W 406/263, ratio 1.54; ventral shield L/W 394/303; gnathosomal bay L 106; distance between most lateral pair of Ac 155, gonopore L/W 29/35, 0.82; ejaculatory complex L 93. Palp: total L 193, dL/H, $\mathrm{dL} / \mathrm{H}$ ratio: P-1, 31/14, 2.2; P-2, 43/34, 1.27; P-3, 28/22, 1.24; P-4, 64/15, 4.2; P-5, 27/8, 3.4 L ratio P2/P-4, 0.67; gnathosoma vL 43, with apodemes 72; chelicera total L 100, claw L 39, basal segment L 62, L basal segment/claw ratio 1.59. Legs: dL of I-L: 33, $33,29,51,68,73$; dL of IV-L: 56, 68, 54, 75, 89, 88.

Female: Dorsal shield L/W 416/275, ratio 1.51; ventral shield L/W 403/322; gnathosomal bay $\mathrm{L}$ 106; distance between most lateral pair of Ac 153, gonopore W 67; egg (n-1) maximum diameter 150. Palp: total L 188, dL/H, dL/H ratio: $\mathrm{P}-1,31 / 13,2.4$; P-2, 43/35, 1.24; P-3, 26/23, 1.14; P-4, 62/15, 4.0; P5, 26/8, 3.3; L ratio P-2/P-4, 0.7. Legs: dL of I-L: 34, $35,31,45,55,65$; dL of IV-L: 53, 63, 58, 73, 79, 86.

Etymology - Named after the country where the new species was found.

Remarks - Due to the presence of posteriorlydirected denticles on the dorsal shield, a long longitudinal ridge posterior to IV-L insertions, and lateral projections on the sides of the ventral shield, the new species most closely resembles to Hexaxonopsis rucira (Cook, 1967), from India. The latter species differs in having smaller and bluntly pointed projections on the lateral margins of the ventral shield and a more or less uniform blue colour of dorsum (Cook 1967).

Distribution - Laos; known only from the locus typicus (Figure 25A).

\section{Hexaxonopsis (Hexaxonopsis) cambodiensis n. sp. (Figures 15C-D, 16-17)}

Type material - Holotype male, dissected and slide mounted, Cambodia, 15-35-1 Angkor, moat around the main Angkor temple, $13^{\circ} 24^{\prime} 54.0^{\prime \prime} \mathrm{N}$, $103^{\circ} 51^{\prime} 34.8^{\prime \prime} \mathrm{E}$, alt. $26 \mathrm{~m}$ a.s.1., depth 0.4-0.2 m, substrate: red sand covered by detritus. Paratypes: $2 / 1 / 0$, same data as holotype, one male and one female dissected and slide mounted. 


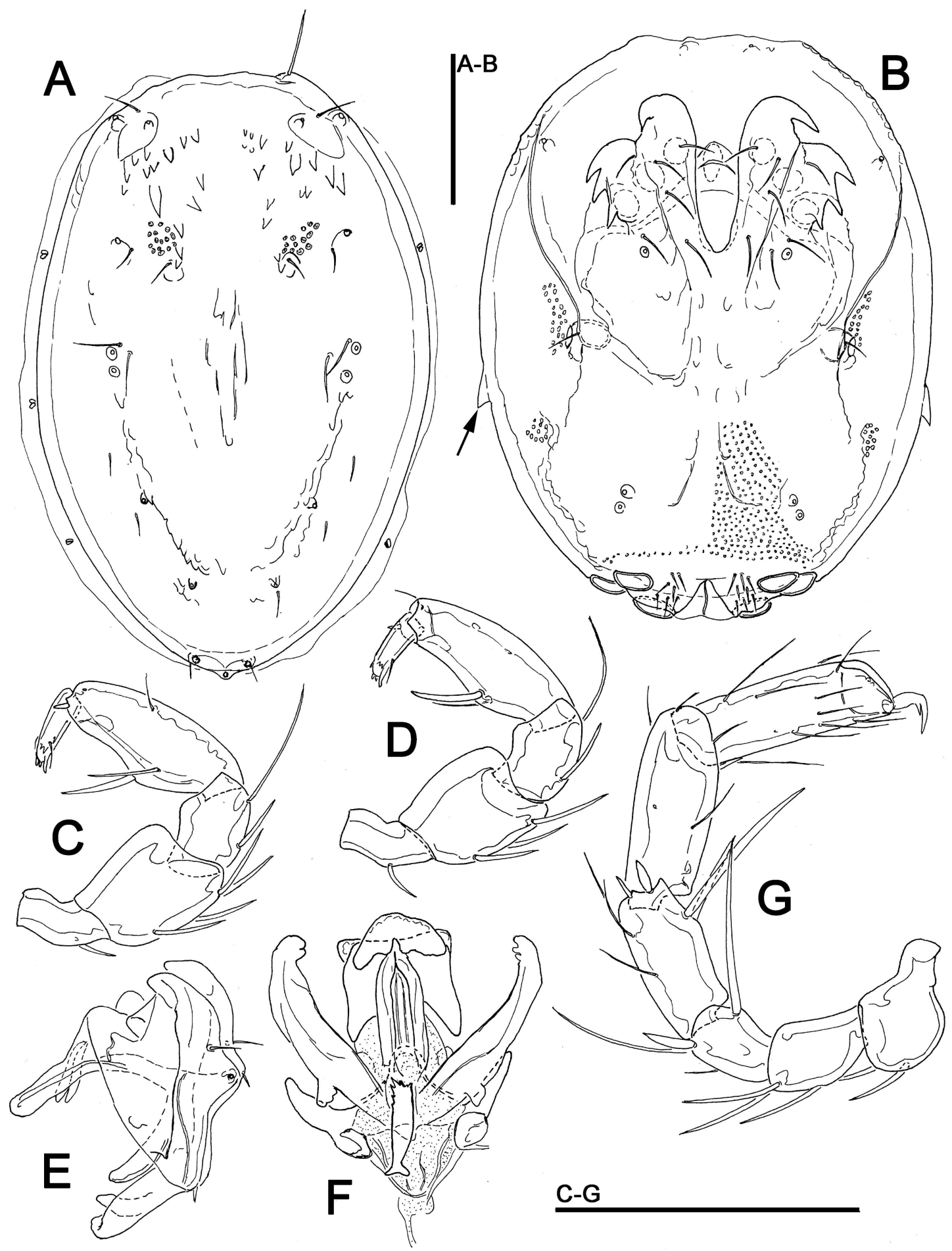

FIGURE 13: Hexaxonopsis (Hexaxonopsis) laosensis n. sp., male, Kauangxi Waterfall, Laos: A - dorsal shield; B - ventral shield (arrow showing the projection on the lateral margin of the ventral shield); C-D - palp; E - gnathosoma; F - ejaculatory complex; G - I-L. Scale bars $-100 \mu \mathrm{m}$. 
Pešić V. and Smit H.

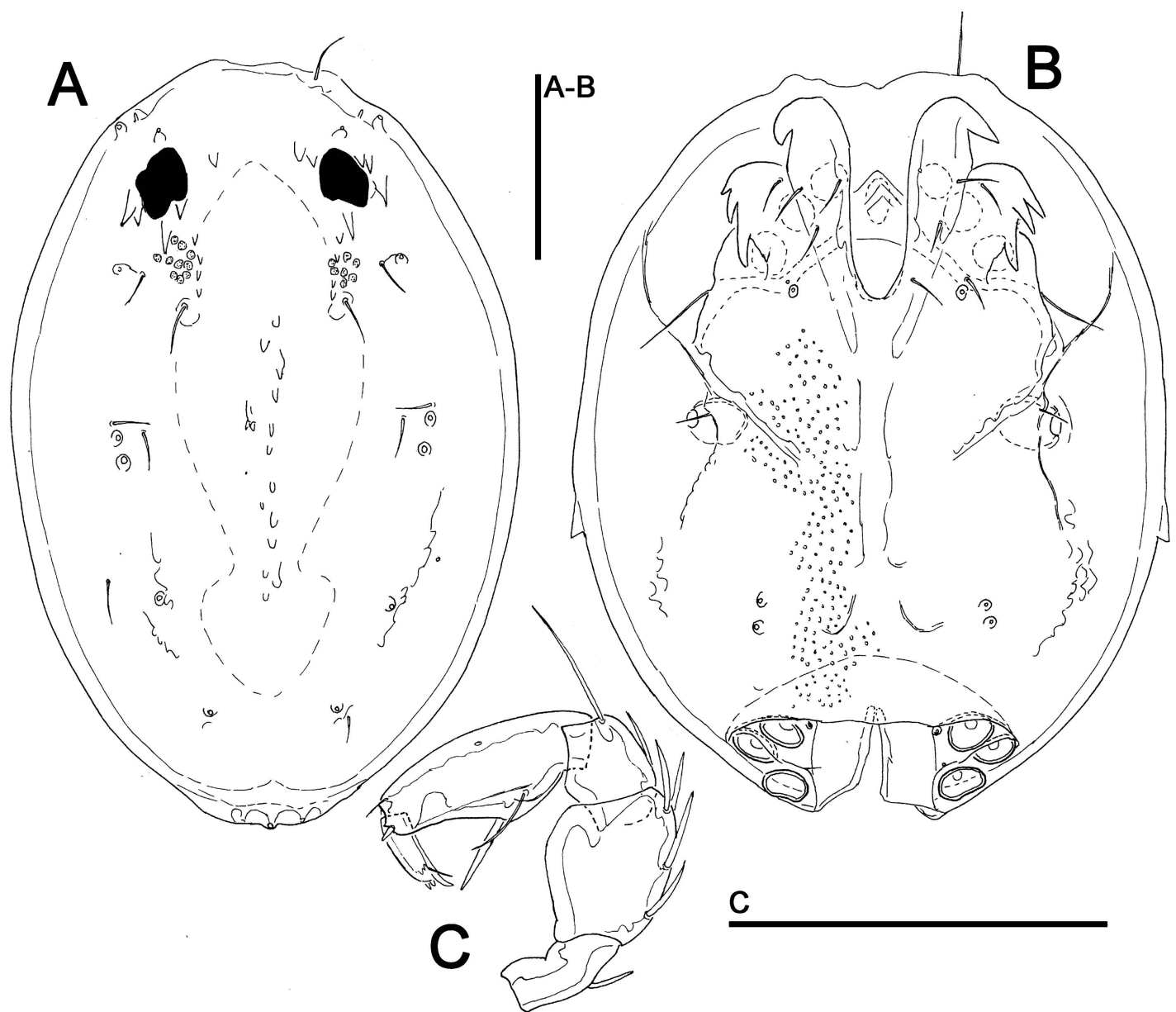

FIGURE 14: Hexaxonopsis (Hexaxonopsis) laosensis n. sp., female, Kauangxi Waterfall, Laos: A - dorsal shield; B - ventral shield; C - palp Scale bars $-100 \mu \mathrm{m}$. 

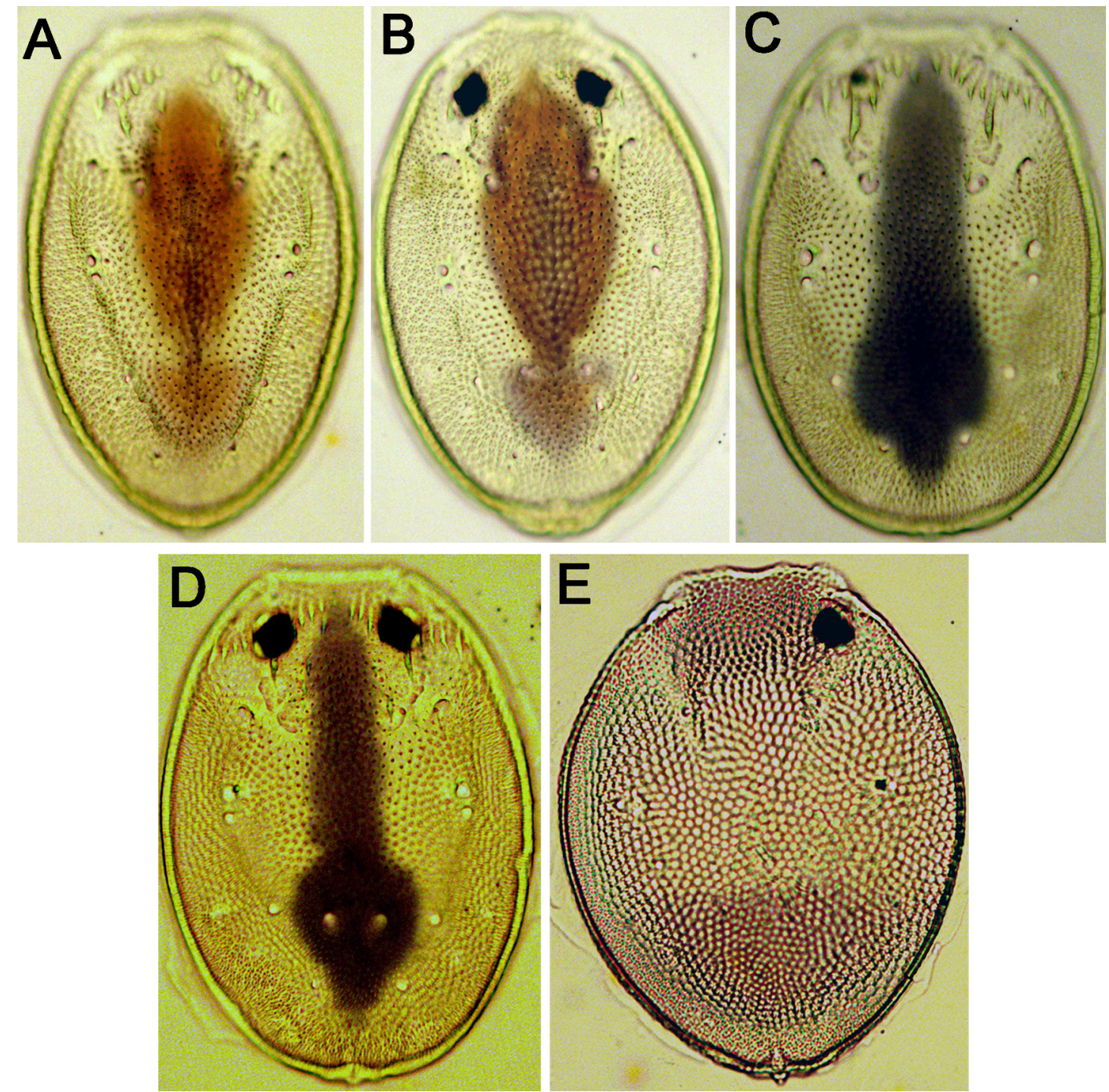

FIGURE 15: Photoghraphs of dorsal shield. A-B Hexaxonopsis laosensis n. sp.: A - male holotype; B - female paratype. C-D H. cambodiensis n. sp.: A - male holotype; B - female paratype. E - H. angkoriensis n. sp., female holotype. 


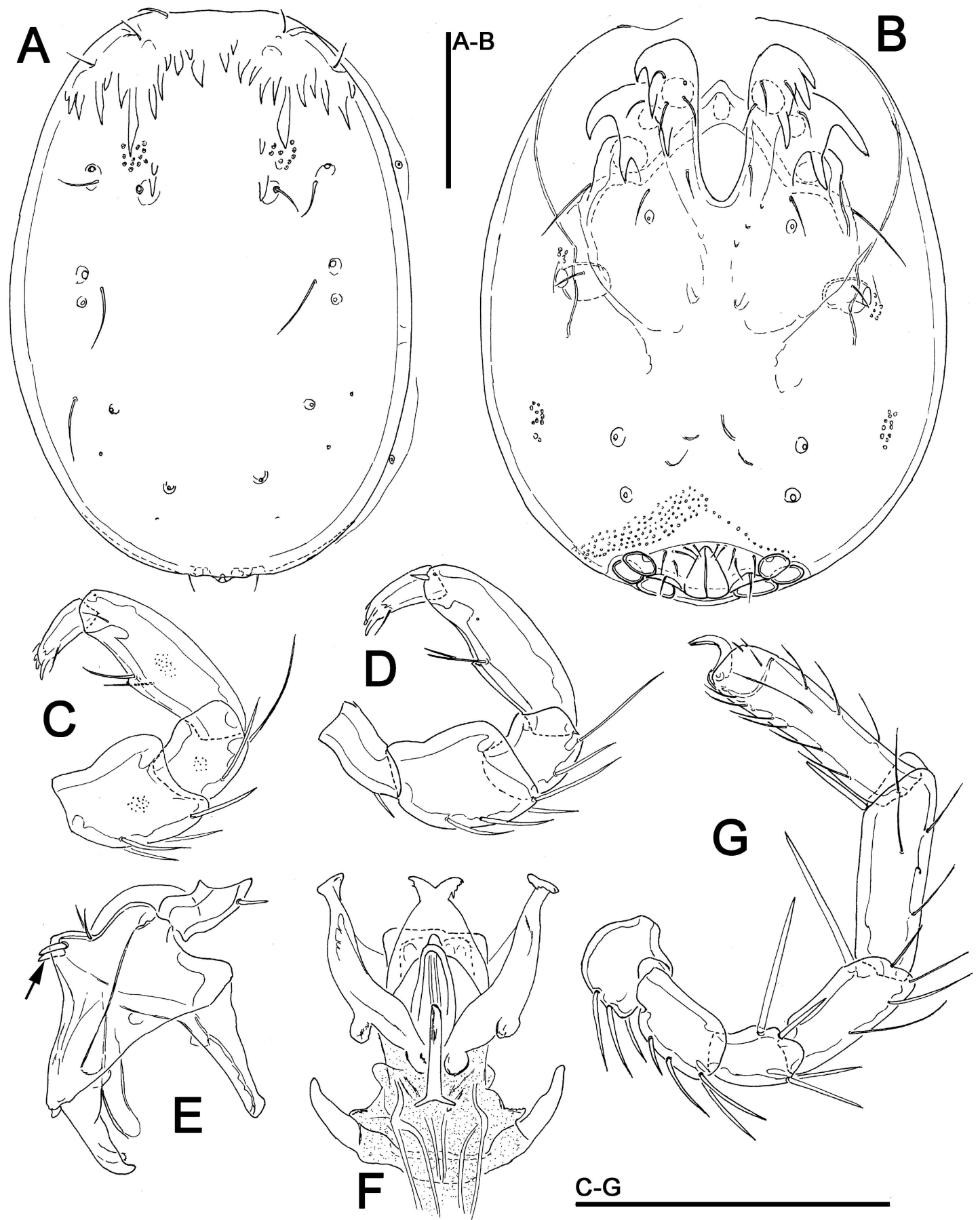

FIGURE 16: Hexaxonopsis (Hexaxonopsis) cambodiensis n. sp., male, Angkor Wat, Cambodia: A - dorsal shield; B - ventral shield; C - palp (P-1 lacking); D - palp; E - gnathosoma (arrow showing enlarged posterior setae); F - ejaculatory complex; G - I-L. Scale bars - 100 $\mu \mathrm{m}$. 


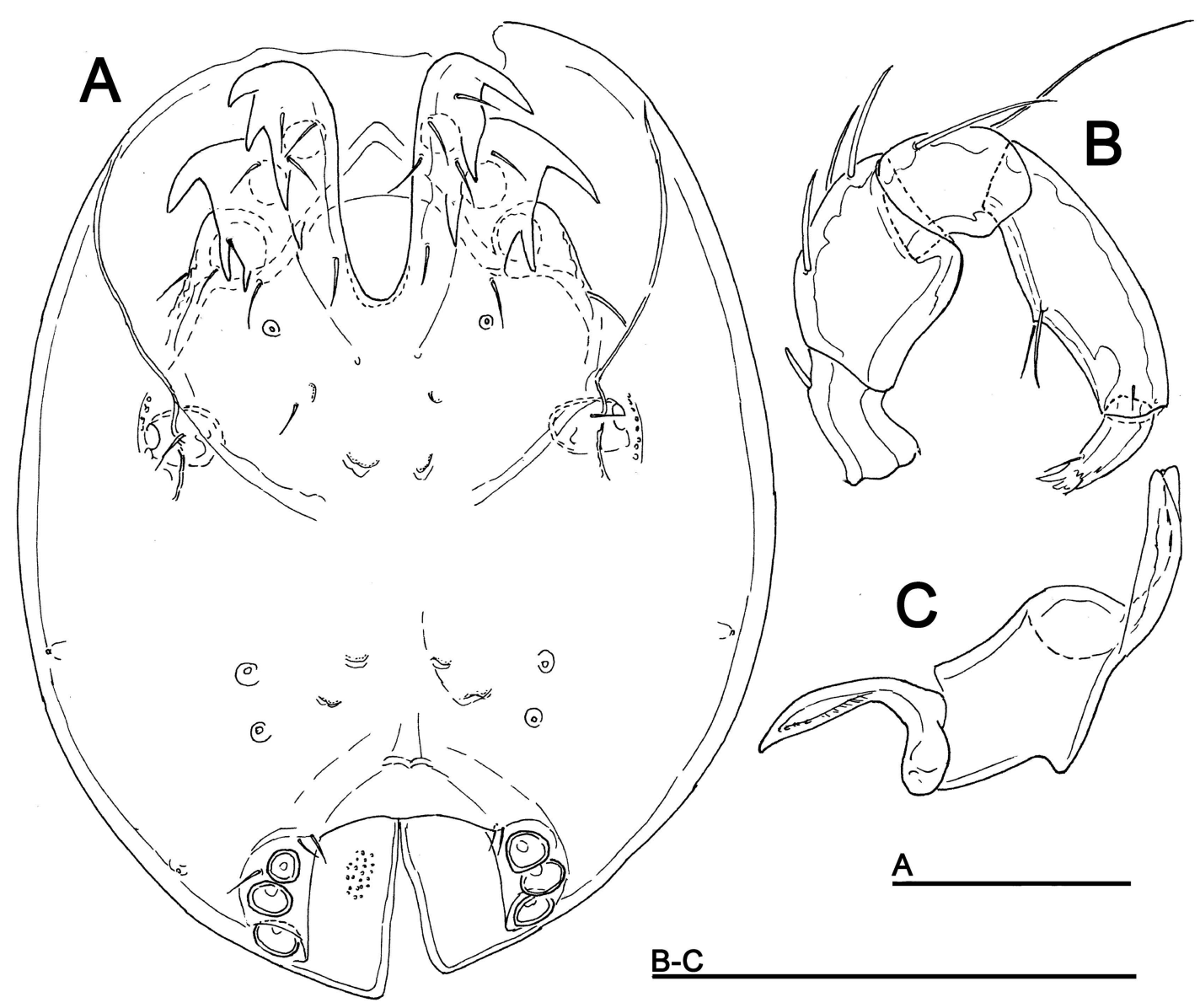

FIGURE 17: Hexaxonopsis (Hexaxonopsis) cambodiensis n. sp., female, Angkor, Cambodia: A - ventral shield; B - palp; C - chelicera. Scale bars $-100 \mu \mathrm{m}$. 
Diagnosis - Colour pattern consisting of a central elongated patch of dark-blue; two pairs of glandularia in region between genital field and opening for insertion of IV-L separated from each other; posterior setae on gnathosoma enlarged.

Description - Dorsal and ventral shields fused anteriorly; dorsal shield with seven pairs of glandularia (the seventh pair inconspicuous, flanking the excretory pore); postocularia well distanced from anterior margin; excretory pore projecting, located at the posterior end of dorsal shield; anterior portion of dorsal shield with 14-15 pairs of triangular, posteriorly-directed denticles (Figure 16A); dorsal shield with colour pattern as illustrated in Figures 15C-D; eye pigment well developed. Ventral shield oval, slightly truncate at anterior end, lateral margins rounded. Lateral margins of Cx-I/II with 2-3 strong, hook-like, posteriorly-directed projections; two pairs of glandularia in region between genital field and opening for insertion of IV-L, these are well separated from each other; a relatively short longitudinal ridge posterior to IV-L insertions. Genital field with three pairs of Ac, arranged in an arc. Palp: ventral margin of P-2 convex, distal margin of P-3 with well developed hyaline extensions, P-4 ventrally dilated near insertions of a pair of hairlike setae, and with a more robust seta near distal end of the segment; posterior setae on gnathosoma enlarged (Figure 16E). Legs: numbers of swimming setae: II-L-4, 1; II-L-5, 2-3; III-L-4, 2; III-L-5, 3; IVL-4, 2; IV-L-5, 2-3. Male: Gonopore elongated. Female: Gonopore relatively large (Figure 17A).

Measurements - Male (holotype, in parentheses paratype): Dorsal shield L/W 372 (372)/266 (259), ratio 1.4 (1.44); ventral shield L/W 381 (399)/301 (294); gnathosomal bay L 103 (102); distance between most lateral pair of Ac 129 (128), gonopore L/W 38 (41)/31 (39), ratio 1.22 (1.05); ejaculatory complex L 99. Palp: total L 195 (200), dL/H, dL/H ratio: P-1, 30/17, 1.8 (31/16, 1.9); P-2, 45/35, 1.28 (45/34, 1.3); P-3, 25/23, 1.07 (25/23, 1.1); P-4, 66/16, 4.1 (69/15, 4.5); P-5, 29/11, 2.6 (30/11, 2.7); $\mathrm{L}$ ratio P-2/P-4, 0.69 (0.65); gnathosoma vL 51 (55), with apodemes 78 (80). Legs: dL of I-L: 32 (34), 32 (32), 29 (27), 49 (49), 65 (68), 72 (75); dL of IV-L: 43 (42), 65 (62), 58 (57), 71 (71), 79 (82), 86 (92).
Female: Dorsal shield L/W 384/272, ratio 1.41; ventral shield L/W 403/320; gnathosomal bay L 100; distance between most lateral pair of Ac 139, gonopore W 86. Palp: total L 189, dL/H, dL/H ratio: P-1, 29/14, 2.1; P-2, 44/33, 1.33; P-3, 25/23, 1.1; P-4, 63/15, 4.1; P-5, 28/10, 2.8; L ratio P-2/P-4 0.7; gnathosoma vL 57, with apodemes 82 ; chelicera total L 104. Legs: dL of I-L: $31,32,29,46,62,68$; dL of IV-L: 42, 62, 57, 69, 78, 88.

Etymology - Named after the country where the new species was found.

Remarks - The combination of posteriorly directed denticles on the dorsal shield, a short longitudinal ridge posterior to IV-L insertions, and absence of the lateral projections on the sides of the ventral shield, makes the new species most similar to Hexaxonopsis paxillatus (Uchida \& Imamura, 1951), a species described by Uchida and Imamura (1951) from central China. The latter species can be separated in different arrangement of dorsal glandularia and the two pairs of glandularia located between genital field and insertions of the IV-L are more closely approached to each other. In the original description Uchida and Imamura (1951) did not mention the colour pattern. Moreover, at the illustrated figure of gnathosoma of A. paxillatus enlarged posterior setae which are so characteristic of the present new species are completely missing (see Uchida and Imamura 1951, figure 8d).

Distribution - Cambodia; known only from the locus typicus (Figure 25D).

\section{Hexaxonopsis (Hexaxonopsis) angkoriensis n. sp. (Figures 15E, 18)}

Type material - Holotype female, dissected and slide mounted, Cambodia, 15-35-1 Angkor, moat around the main Angkor temple, $13^{\circ} 24^{\prime} 54.0^{\prime \prime} \mathrm{N}$, $103^{\circ} 51^{\prime} 34.8^{\prime \prime E}$, alt. $26 \mathrm{~m}$ a.s.l., depth 0.4-0.2 m, substrate: red sand covered by detritus.

Diagnosis - (Male unknown). Dorsal shield colour indistinct; lateral margins posterior to IV-L insertions with developed triangular projection on each side of ventral shield.

Description - Female: Dorsal and ventral shields lightly fused anteriorly; dorsal shield with 

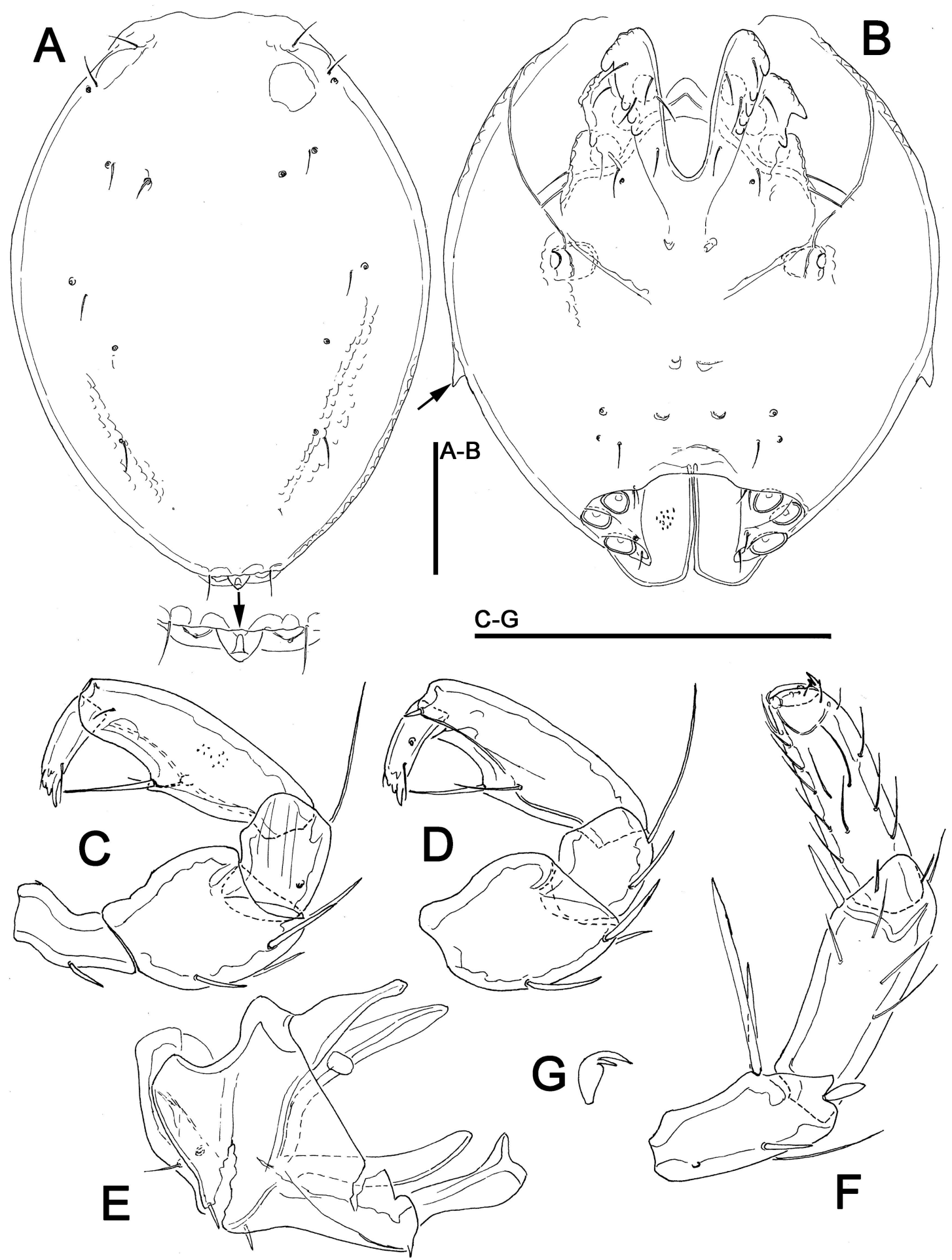

FIGURE 18: Hexaxonopsis (Hexaxonopsis) angkoriensis n. sp., male, Angkor, Cambodia: A - dorsal shield; B - ventral shield (arrow showing the projection on the lateral margin of the ventral shield); C - palp; D - palp (P-1 lacking); E - gnathosoma; F - I-L-4-6 ; G - II-L claw. Scale bars $-100 \mu \mathrm{m}$. 
six pairs of small glandularia (the sixth pair inconspicuous, flanking the excretory pore); postocularia well distanced from anterior margin; excretory pore projecting, located at the posterior end of dorsal shield (Figure 18A); dorsal shield colour indistinct (Figure 18E); eye pigment well developed. Ventral shield oval, slightly truncate at anterior end, lateral margins with well developed triangular projection on each side (Figure 18B) posterior to IV-L insertions. Lateral margins of $\mathrm{Cx}-\mathrm{I} / \mathrm{II}$ with several, blunt and posteriorly-directed projections; two pairs of glandularia (posterior one visible as a pair of distinct pores and could be interpreted as the remnants of a second pair of glandularia) located between insertions of the IV-L and genital field. Genital field with three pairs of Ac, arranged in an arc. Palp: ventral margin of $\mathrm{P}-2$ convex, distal margin of $\mathrm{P}-$ 3 with well developed hyaline extensions, middle of ventral side of P-4 expanded, bearing relatively long and heavy seta (Figure 18C-D). Legs: numbers of swimming setae: II-L-5, 2; III-L-4, 2; III-L-5, 3; IVL-4, 2; IV-L-5, 3.

Measurements - Dorsal shield L/W 440/320, ratio 1.38; ventral shield L/W 434/378; gnathosomal bay L 110; distance between most lateral pair of Ac 174, gonopore W 77. Palp: total L 214, dL/H, dL/H ratio: P-1, 35/15, 2.3; P-2, 49/39, 1.26; P-3, 26/25, 1.03; P-4, 73/25, 2.9; P-5, 31/10, 3.1; dL ratio P-2/P-4, 0.67; gnathosoma vL 56, with apodemes 91. Legs: dL of I-L: $35,39,34,51,72,70$; dL of IV-L: $45,70,59,74,82,84$.

\section{Male: Unknown.}

Etymology - Named after the country where the new species was collected.

Remarks - The new species resembles Hexaxonopsis bharatensis Cook, 1967 from India, due to the absence of a longitudinal ridge posterior to IV-L insertions, the lack of posteriorly-directed denticles on the dorsal shield and the similar morphology of palp. The latter species can be distinguished from A. angkoriensis $\mathbf{n}$. sp. by the lacking projections on the lateral margin of the ventral shield, the sharppointed hook-like extensions of the coxae and the characteristic colour pattern of the dorsum consisting of a central elongated blue patch (Cook 1967).
Distribution - Laos; known only from the locus typicus (Figure 25D).

\section{Genus Javalbia K. Viets, 1935 \\ Subgenus Javalbia s. str.}

\section{Javalbia (Javalbia) vietnamica n. sp. (Figure 19)}

Type material - Holotype male, dissected and slide mounted, Vietnam, 15-41-1, Bach Má National Park, 5-falls-brook, $16^{\circ} 11^{\prime} 33^{\prime \prime} \mathrm{N}, 107^{\circ} 51^{\prime} 21^{\prime} \mathrm{E}$, alt. $1210 \mathrm{~m}$ a.s.l., pool with detritus of leaves, 1.v.2015.

Diagnosis - Anterior lateroglandularia fused with dorsal shield; postocularia lying much closer and at the same level of glandularia pair; genital field with four pairs of acetabula; I-L-6 distally strongly tapering.

Description - Male: Idiosoma egg-shaped. Posterior margin of the dorsal shield forming an indistinct cauda. Dorsal shield flanked by three pairs of lateroglandularia in posterior half of the dorsal furrow, anterior lateroglandularia fused with dorsal shield (Figure 19A): postocularia at the same level of glandularia pair; A2 fused with dorsal shield. Genital field with four pairs of acetabula (Figure 19B). Genital field fused with ventral shield, suture lines indistinct. Palp slender, P-2 ventral margin straight, P-3 ventral margin concave, P-4 with convex dorsal and almost straight ventral margins bearing two fine ventral setae (one of them elongated) (Figures 19C-D). Glandularia (Vgl-4) flanking genital field on enlarged platelets in posterolateral indentations of the ventral shield. Excretory pore on a transverse oval platelet immediately posterior to genital field. Legs: I-L-6 distally strongly tapering; swimming setae absent.

Measurements - Dorsal shield L/W 442/303; ventral shield (including genital field) $\mathrm{L} / \mathrm{W}$ $422 / 369$, gnathosomal bay 88 ; $\mathrm{W}$ between the most lateral pair of Ac 109, gonopore L/W 43/30, ratio 1.43; ejaculatory complex L 81 . Palp: total L 183 , $\mathrm{dL} / \mathrm{H}, \mathrm{dL} / \mathrm{H}$ ratio: $\mathrm{P}-1,22 / 15,1.5 ; \mathrm{P}-2,39 / 26,1.49$; P-3, 31/22, 1.44; P-4, 62/15, 4.1; P-5, 29/8, 3.4; L ratio P-2/P-4, 0.63; gnathosoma vL 69; chelicera total L 123. Legs: dL of I-L: $35,29,42,51,54,52$; dL of IV-L: 75, 48, 65, 69, 71, 68. Female: Unknown. 


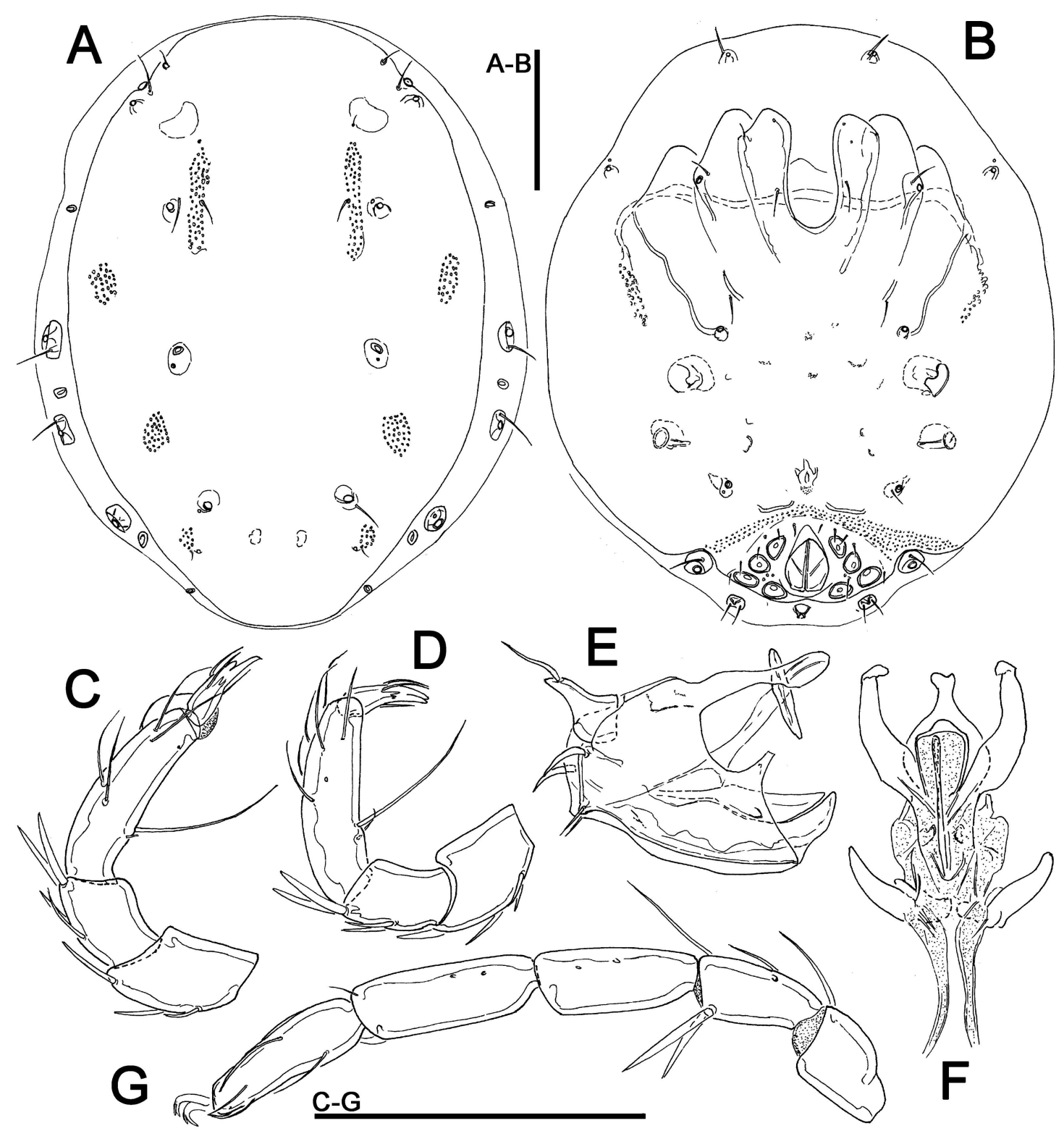

FIGURE 19: Javalbia (Javalbia) vietnamica n. sp., male, Bach Má National Park, Vietnam: A - dorsal shield; B - ventral shield; C - palp (P-1 lacking); D - palp; E - gnathosoma; F - ejaculatory complex; G - I-L-2-6. Scale bars - $100 \mu \mathrm{m}$. 
Etymology - Named after the country where the new species was found.

Remarks - Due to the presence of four pairs of acetabula the new Javalbia species from Vietnam should be assigned to the subgenus Javalbicula K.O. Viets, 1974. This subgenus includes three species, i.e. J. lata K. O. Viets \& Böttger, 1974 (South Africa), J. turcica Esen, Pešić \& Erman, 2011 (Turkey) and J. ovata Kim \& Chung, 1996 (Korea). Recently, Smit (2016) proposes to synonymize Javalbicula with Javalbiopsis Cook, and to transfer the two four-acetabulate species having the excretory pore on a separate platelet (i.e., J. ovata and J. siamis Smit, 2016) to Javalbia s.s. The new species from this study can be separated from J. ovata in I-L-6 distally strongly tapering (equally narrowed in J. ovata, see Kim and Chung 1996). Javalbia siamis from Thailand differs from the species from our study in freelying anterolateral dorsal glandularia and the postocularia distanced and posteromedially from the nearest pair of dorsal glandularia (Smit 2016).

Distribution - Vietnam; known only from the locus typicus.

\section{Genus Sinaxonopsis Yi \& Jin, 2014}

\section{Sinaxonopsis laosensis $\mathbf{n} . \mathbf{s p}$.} (Figures 20-21)

Type material - Holotype male, dissected and slide mounted, Laos, 15-33-1, Kouangxi Waterfall, lentic bay within a pool behind a travertine barrier within the main brook, $19^{\circ} 44^{\prime} 55.9^{\prime \prime} \mathrm{N}, 101^{\circ} 59^{\prime} 33.4^{\prime \prime} \mathrm{E}$, alt. ca. $490 \mathrm{~m}$ a.s.l., water depth $0.5 \mathrm{~m}$, substrate: travertine mud covered by some leaves.

Diagnosis - Dorsal posterior plate bearing six pairs of glandularia (Dgl-2-4, and Lgl-2-4); Cx-IV with distinct medial suture line; Palp slender $(\mathrm{L} / \mathrm{H}$ $\mathrm{P}-2$, 2.2; P-4, 5.0); IV-L-4 distally with a strong bifurcated seta, IV-L-5 distally with a strong pennate seta; IV-L-6 anteriorly slightly enlarged, posteriorly with three strong, laterally flattened setae.

Description - Male: Idiosoma colourless; dorsal and ventral shield present; dorsal shield formed by a large posterior plate bearing six pairs of glandularia (Dgl-2-4, and Lgl-2-4) and one pair of anterior platelets bearing the lateral eyes, postocularia,
A2 and Dgl-1 (Figure 20A); excretory pore projecting, located at the posterior end of dorsal shield; dorsal shield colour indistinct, eye pigment well developed. Ventral shield (Figure 20B) oval, slightly truncate at anterior end; tips of Cx-I not extending beyond frontal margin. Cx-IV with distinct medial, posterior and lateral suture lines, medial suture line straight, suture line Cx-III/IV developed only laterally, ending medial to IV-L insertions and not reaching the medial line; genital field triangular, gonopore elongated, acetabula numerous (approximately 30 pairs of acetabula, but due to rugosity of idiosoma some of these not visible in ventral view) and extend in parallel to the coxal plate margin as indistinct strips from the gonopore to the posterolateral idiosoma edge.

Palp: P-2-3 ventral margin slightly concave, P-4 longer than $\mathrm{P}-2$, basally and distally concave, in centre convex with a pair of long setae (Figures 20D-E).

Legs: ventral margin of I-L-6 and II-L-6 with small denticles and a dense hair-like setae (Figures 21A-B); III-L-4 with dorsal and ventral margins diverging from base to tip, distal margin bearing two sword setae and two strong simple setae; III-L-5 slightly curved, distally with one strong sword seta, slightly set off from distal margin, and several slender simple setae; III-L-6 not bearing modified setae, claws modified and heteromorphic as illustrated in Figure 21C (inset); IV-L-4 with dorsal and ventral margins diverging from base to tip, in the enlarged distal half a group of strong, variously modified setae, one strong bifurcated (Figure 21D, arrow), two strong sword setae, and two simple slender setae; IV-L-5 ventral margin almost straight, distally not remarkably thicker distally than proximally, distally in addition to one strong sword seta, slightly set off from distal margin, one pennate and two slender simple setae; IV-L-6 slightly curved, anteriorly slightly enlarged, posteriorly with three strong, laterally flattened setae; claws of I-III legs with a dorsal and ventral clawlets (Figure 21A inset).

Measurements - Idiosoma L/W 581/43, dorsal shield L/W 550/438; posterior plate L/W 475/438, anterior platelets L/W 260/85; ventral shield L/W 556/463; gnathosomal bay L 141; gonopore L/W 78/9, ratio 8.5; ejaculatory complex L 172. Palp: 


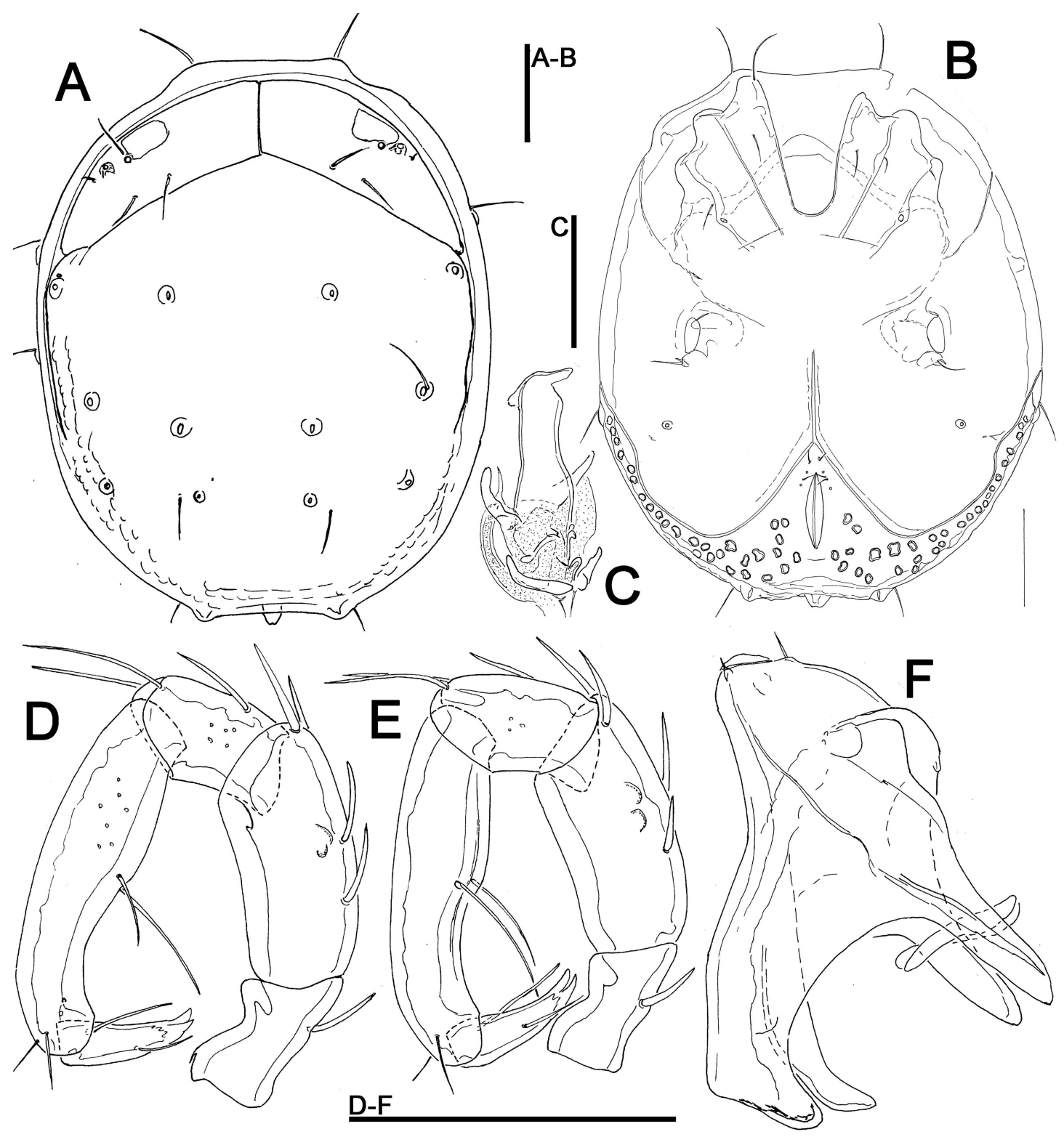

FIGURE 20: Sinaxonopsis laosensis n. sp., male, Kauangxi Waterfall, Laos: A - idiosoma dorsal view; B - ventral shield; C - ejaculatory complex; D-E - palp; F - gnathosoma. Scale bars - $100 \mu \mathrm{m}$. 
Pešić V. and Smit H.

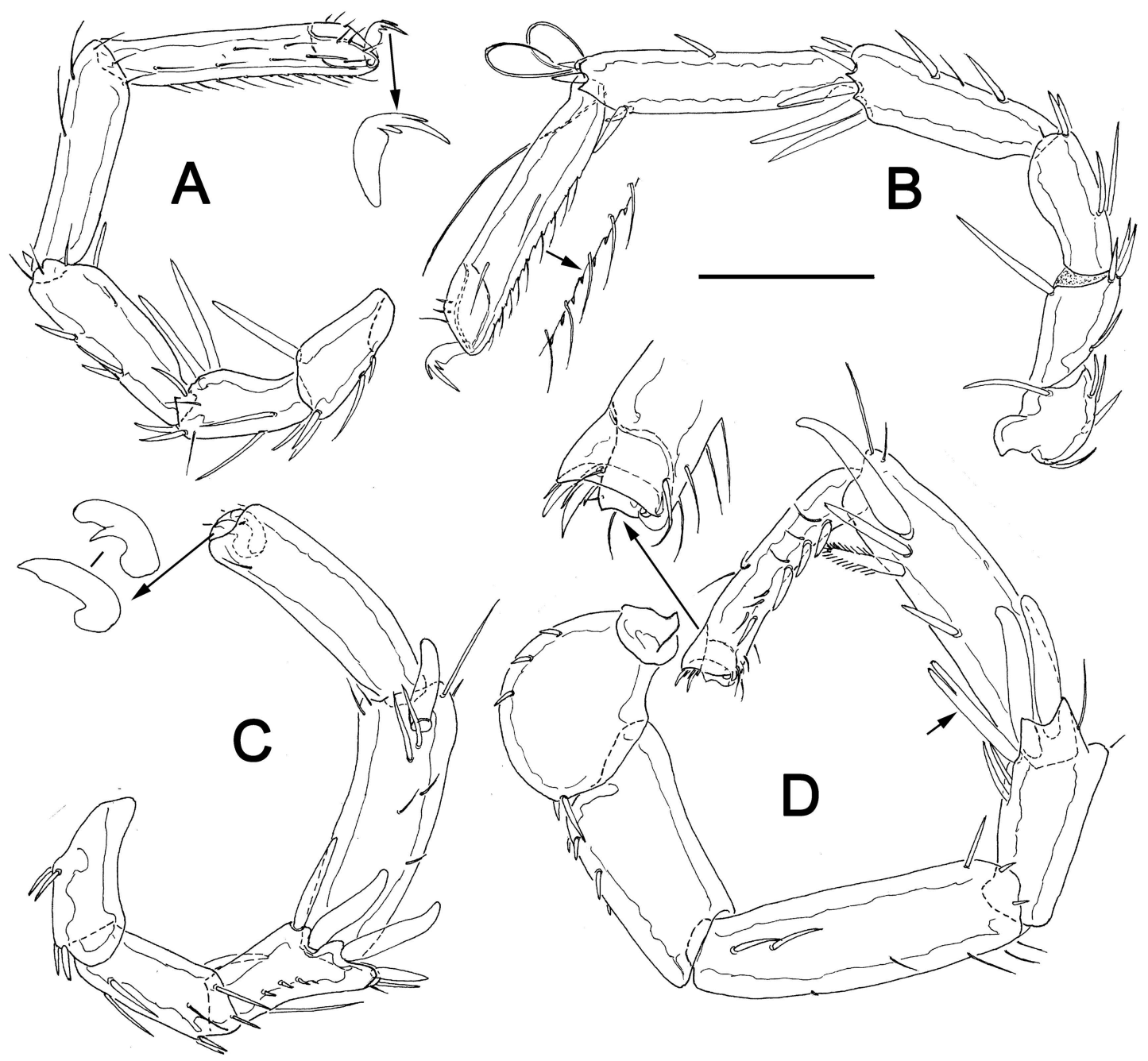

FIGURE 21: Sinaxonopsis laosensis n. sp., male, Kauangxi Waterfall, Laos: A - I-L-2-6 (inset: claw); B - II-L (inset: ventral denticulation of II-L-6); C - III-L-2-6 (inset: claws); D - IV-L (inset: distal margin of IV-L-6) (arrow showing strong bifurcate seta). Scale bars - 100 $\mu \mathrm{m}$. 
total $\mathrm{L} 328, \mathrm{dL} / \mathrm{H}, \mathrm{dL} / \mathrm{H}$ ratio: $\mathrm{P}-1,46 / 20,2.3$; P2, 80/37, 2.16; P-3, 46/29, 1.58; P-4, 111/22, 5.0; P5, 45/14, 3.2; L ratio P-2/P-4, 0.72; gnathosoma $\mathrm{vL}$ 132; chelicera total L 162, claw L 49, basal segment L 123, L basal segment/claw ratio 2.5. Legs: dL of IL-2-6: 57, 75, 115, 145, 157; dL of II-L: $63,65,86,125$, 159, 169; dL of III-L: 77, 59, 89, 89, 181, 159; dL of IVL: $120,129,188,109,212,142$. Female: Unknown.

Remarks - This is the third Sinaxonopsis species, the first one (S. unicucrus Yi \& Jin, 2012) was described by Yi and Jin (2012) from a pool in a stream in Anhui Province, China. The species from China, known from both sexes, differs from Sinaxonopsis laosensis n. sp. in: 1) Cx-IV medially forming pronounced angle, 2) palp segments comparatively more stout (L/H P-2, 1.65; P-4, 4.5; calculated from figures), IV-L-4 distally without strong bifurcated seta, IV-L-5 distally without strong pennate seta, IVL-6 anteriorly strongly enlarged, with a pair of welldeveloped dorsal projections.

Recently, Smit (2016) described, based on a single female, the second species Sinaxonopsis siamicus from Thailand, a species clearly differing in Lgl-2 not on large posterior dorsal shield, a different configuration of Dgl-1 and A2 and comparatively more stouter palp.

Distribution - Laos; known only from the locus typicus (Figure 25A).

\section{Family Krendowskiidae Viets, 1926 Genus Krendowskia Piersig, 1895}

\section{Krendowskia (Krendowskiella) octagonus Lundblad, 1941}

Material examined - Cambodia, 15-34-1 Angkor, ancient swimming pool of the king (named: Srah Srang acc. to Google Earth, 2015), 1325'56.3"N, $103^{\circ} 54^{\prime} 18.5^{\prime \prime E}$, alt. $27 \mathrm{~m}$ a.s.l., water depth $0.1 \mathrm{~m}$, substrate: sand covered by a thin layer of detritus, some submersed macrophytes, 23.iv.2015, 0/1/0.

Distribution - Southeast Asia: Burma (Lundblad 1969) and Cambodia.

\section{Family Athienemanniidae K. Viets, 1922 Genus Africasia K. Viets, 1931}

\section{Africasia purpurea n. sp. (Figures 22-23)}

Type series - Holotype female, dissected and slide mounted, Laos, 15-33-1 Kouangxi Waterfall, lentic bay within a pool behind a travertine barrier within the main brook, $19^{\circ} 44^{\prime} 55.9^{\prime \prime} \mathrm{N}, 101^{\circ} 59^{\prime} 33.4^{\prime \prime} \mathrm{E}$, alt. ca. $490 \mathrm{~m}$ a.s.l., water depth $0.5 \mathrm{~m}$, substrate: travertine mud covered by some leaves.

Diagnosis - (Male unknown). Dorsal colour pattern consisting of anterior and two posterolateral deep purple patches; Cx-IV with a short longitudinal ridge posterior to IV-L insertions; IV-L-4/5 each with one strong distal pennate seta.

Description - Female: Dorsal and ventral shields present; dorsal shield colour pattern as shown in Figure 23A (due to treatment with lactic acid in mounted specimens reddish); eye pigment well developed; ventral shield with steep lateral margins; tips of Cx-I extending beyond frontal margin; Cx-IV posterior to IV-L insertion with a longitudinal ridge; genital plates lightly defined, with numerous pairs of acetabula (Figure 22B); palp segments rotated, distal end of the uncate P-4 with a long antagonistic bristle (Figures 22C-D). Legs: number of swimming setae: II-L-4, 2; II-L-5, 2; IIIL-4, 2; III-L-5, 5; IV-L-4, 2; IV-L-5, 2; IV-L-4/5 each with one dorsodistal pennate seta (Figure 22F).

Measurements - Dorsal shield L/W 356/327, ratio 1.09; ventral shield L/W 434/364; gnathosomal bay L 72; distance between most lateral pair of Ac 195, gonopore L/W 92/74, ratio 1.24. Palp total L 173, dL/H, dL/H ratio: P-1, 25/20, 1.27; P-2, 48/35, 1.38; P-3, 31/32, 0.95; P-4, 58/32, 1.85; P-5, 11/-; L P-2/P-4 ratio 0.82; gnathosoma vL 88; dL of I-L-2-6: 36, 34, 43, 63, 77; dL of IV-L: 65, 57, 50, 74, $86,86$.

Male: Unknown.

Etymology - The name refers to the characteristic colour of the new species.

Remarks - The characteristic colour pattern on the dorsal shield easily separates the new species 
Pešić V. and Smit H.

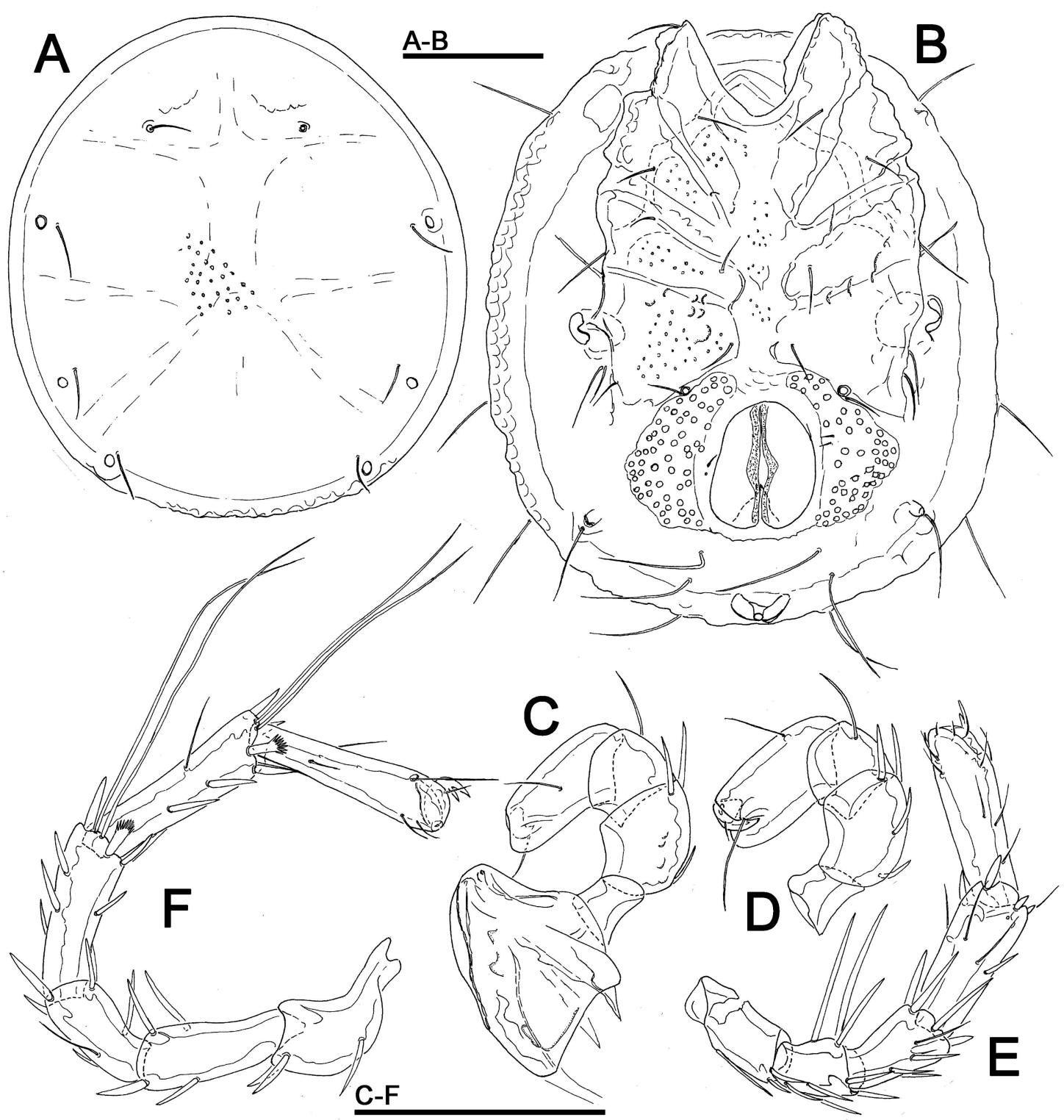

FIgURE 22: Africasia purpurea n. sp., male, Kauangxi Waterfall, Laos: A - dorsal shield; B - ventral shield; C - gnathosoma and palp, medial view; D - palp, lateral view; E - I-L-2-6; F - IV-L. Scale bars - $100 \mu \mathrm{m}$. 

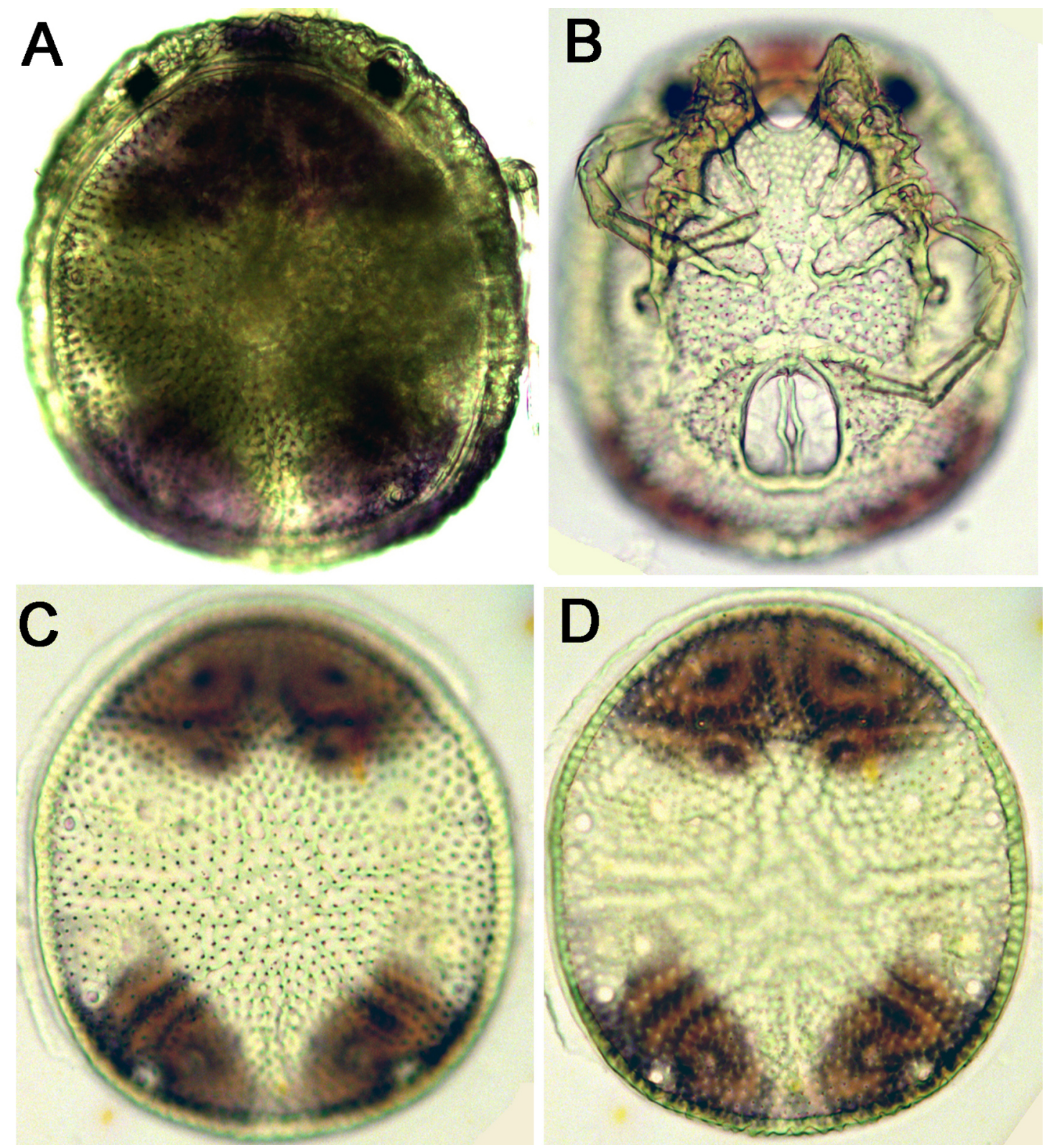

FIGURE 23: Photoghraphs of Africasia purpurea n. sp., male, Kauangxi Waterfall, Laos: A - idiosoma, dorsal view (photographed before dissection); B - ventral shield; C-D - dorsal shield (specimen mounted in Hoyer's medium). 
Pešić V. and Smit H.

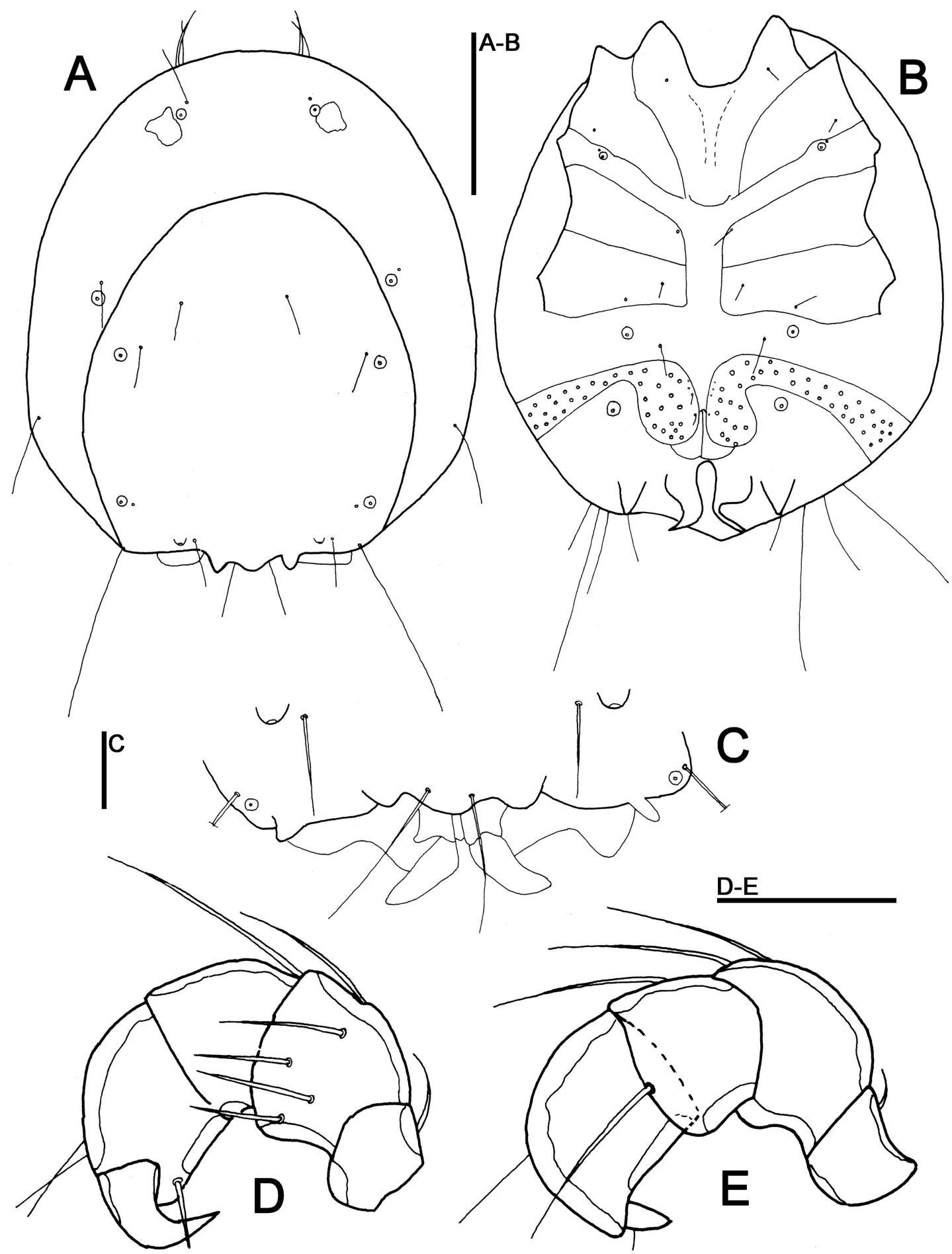

FIgURE 24: Arrenurus contortus n. sp., male, Bach Má National Park, Vietnam: A - dorsal view; B - ventral view; C - detail of posterior idiosoma margin; D - right palp; E - left palp. Scale bars: A-B - $200 \mu \mathrm{m}, \mathrm{D}-\mathrm{E}-50 \mu \mathrm{m}$. 

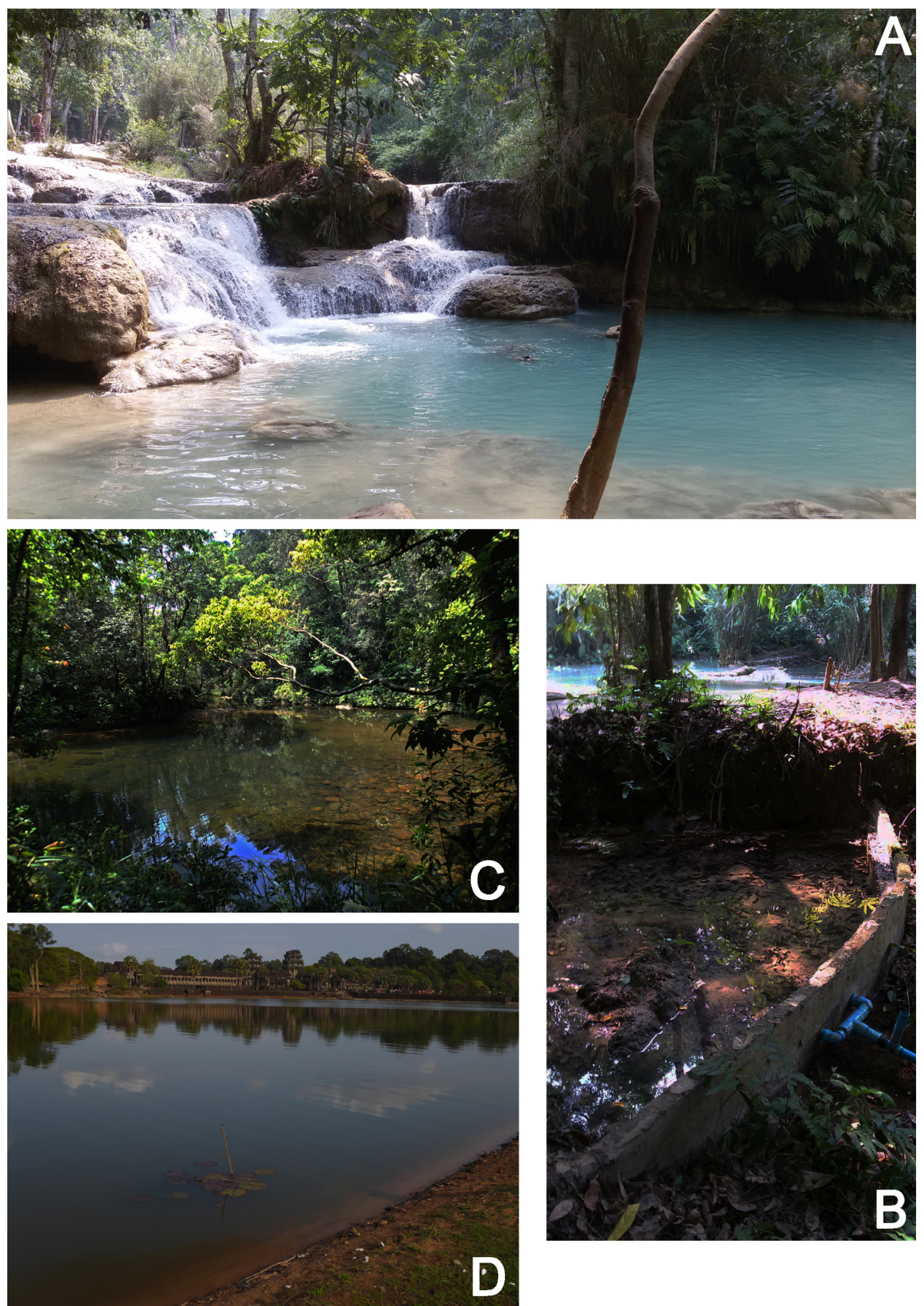

FIgURE 25: Photoghraphs of sampling sites: A - Laos, Kauangxi Waterfall (locus typicus of Monatractides laosensis n. sp., Hexaxonopsis laosensis n. sp., Sinaxonopsis laosensis n. sp. and Africasia purpurea n. sp.); B - Laos, Kouangxi Waterfall, pond behind artifical barrier (sampling site of Hygrobates hamatus K. Viets, 1935, H. henni Wiles, 2004 and locus typicus of Forelia gereckei n. sp.); C - Vietnam, Bach Má National Park, brook with a pool (sampling site of Monatarctides sp. and locus typicus of Limnesia scharfi $\mathbf{n}$. sp., Schwoerbelia pioniformis n. sp. and Arrenurus contortus n. sp.; D - Cambodia, moat around the main Angkor temple (locus typicus of Hexaxonopsis cambodiensis $\mathbf{n}$. sp. and H. angkoriensis $\mathbf{n}$. sp.) 
from all other members of the genus. Other diagnostic features of the new species include Cx-IV with lateral ridges posterior to IV-L insertion, and the presence of one strong pennate seta on IV-L-4/5 each.

Distribution - Laos; only known from the locus typicus (Figure 25A).

\section{Family Arrenuridae Thor, 1900 Genus Arrenurus Dugès, 1834}

\section{Arrenurus (Micruracarus) contortus n. sp. (Figure 24)}

Type series - Holotype male, dissected and slide mounted, Vietnam, 15-44-1 Bach Má National Park, brook with a pool behind a natural barrier, $16^{\circ} 11^{\prime} 15.5^{\prime \prime} \mathrm{N}, 105^{\circ} 50^{\prime} 54.7^{\prime \prime} \mathrm{E}$, alt. $1130 \mathrm{~m}$ a.s.l., water depth $0.2 \mathrm{~m}$, substrate: leaves in a lentic bay, 2.v.2015.

Diagnosis - Petiole consisting of hyaline appendages; posterior dorsal margin with a pair of double-lobed hyaline membranes; genital plates reversed wing-shaped, broadening laterally; gonopore very narrow.

Description - Male: Idiosoma lilac, dorsally 603 long and 543 wide. Dorsal shield complete, 381 wide. Dgl-3, Dgl-4 and Lgl-4 (conform Wiles 1997) not well visible in dorsal view due to bowing of the dorsal shield. Pygal lobes absent. Posterior dorsal margin with a pair of two-lobed hyaline membranes. Posterior margin ending in a blunt, rounded projection, flanked by a pair of knob-like extensions. Cx-I extending beyond anterior idiosoma margin. Distance of tip of Cx-I to posterior idiosoma margin $640 \mu \mathrm{m}$. Genital plates reversed wing-shaped, broadening laterally, slightly extending onto lateral idiosoma margin. Gonopore very narrow, $60 \mu \mathrm{m}$ long. Idiosoma posteromedially with a concavity, with the petiole in it. Petiole consisting of two hyaline appendages, their shape dependent on position of the specimen. Besides the hyaline petiole a double-tipped hyaline appendage present. Palp: total L 214, dL: P-1, 28; P-2, 52; P-3, 42; P-4, 54; P-5, 38; P-2 medially with four setae, dorsally with three setae; P-3 with a long medial seta. Legs: dL of I-L-4-6: 86, 86, 76; dL of IV-L-4-6:
122, 112, 92; IV-L-4 without a spur. Third and fourth legs with numerous swimming setae. Female: Unknown.

Etymology - Named for the complicated structure of the appendages.

Remarks - The shape of the genital plates is very unusual, and thus far found in the subgenus Rhinophoracarus Viets, 1916 and in a small number of other subgenera. However, members of Rhinophoracarus have a very long petiole, very unlike the hyaline petiole of the new species. Due to the presence of a hyaline petiole and hyaline appendages assignment to Micruracarus seems most appropriate.

Distribution - Vietnam; only known from the locus typicus (Figure 25C).

\section{ACKNOWLEDGEMENTS}

We are indebted to Burkhard Scharf (Bremen, Germany), the collector of the mites described here and to Reinhard Gerecke (Tübingen, Germany) for sending the mites to first author. David Cook (Paradise Valley, USA) helped with comments on the status of the new genera.

\section{REFERENCES}

Cook D.R. 1967 — Water mites from India - Mem. Amer. Ent. Inst., 9: 1-411.

Cook D.R. 1974 - Water mite genera and subgenera Mem. Amer. Ent. Inst., 21: 1-860.

Gerecke R., Weigmann G., Wohltmann A., Wurst E. 2007 - Order Acari - General introduction and key to major groups - In: Gerecke, R. (Ed), Süßwasserfauna von Mitteleuropa. Vol. 7. 2-1. München. Elsevier Spektrum Akademischer Verlag, p. 14-57.

Goldschmidt T., Koehler G. 2007 - New species of the Hygrobates salamandrarum - group (Acari, Hydrachnidia, Hygrobatidae) from Southeast Asia - Zool. Anz., 246: 73-89. doi:10.1016/j.jcz.2007.01.001

Jin D.-C. 1995 - A newly recorded genus in Chinese water mite fauna with description of a new species Forelia flexipoda sp. nov. (Acari: Hygrobatoidea: Pionidae) Acta Zool. Sin. 20(3): 332-335.

Jin D.-C. 1997 - Hydrachnellae - Morphology, Systematics. A primary study of chinese fauna - Guizhou Science and Technology Publishing House, pp. 356. 
Kim I.-H., Chung K.-S. 1996 - Water mites of Axonopsinae (Acarina, Aturidae) from Korea - Korean J. Syst. Zool., 12: 137-165.

Lundblad O. 1969 - Indische Wassermilben, hauptsächlich von Hinterindien - Ark. Zool., 22: 289-443.

Pešić V., Chatterjee T., Bordoloi S. 2010 - A checklist of the water mites (Acari: Hydrachnidia) of India, with new records and description of one new species Zootaxa, 2617: 1-54.

Pešić V., Smit H. 2009 - Water mites of the family Torrenticolidae Piersig, 1902 (Acari: Hydrachnidia) from Thailand, Part II. The genus Monatractides K.Viets Zootaxa, 2012: 1-27.

Pešić V. 2013 - A remarkable new Nilotonia species (Acari, Hydrachnidia, Anisitsiellidae) from percolating water of a cave in Cat $\mathrm{Ba}$ island in Halong Bay, Vietnam - Zootaxa, 3710(4): 372-380. doi:10.11646/zootaxa.3710.4.6

Pešić V., Gerecke R. 2014 - Water mites from caves of the Ha Giang province, northern Vietnam - Zootaxa, 3774(4): 367-380. doi:10.11646/zootaxa.3774.4.5

Pešić V., Smit H. 2014a - Torrenticolid water mites (Acari: Hydrachnidia: Torrenticolidae) from Ghana Zootaxa, 3820(1): 1-80. doi:10.11646/zootaxa.3820.1.1

Pešić V., Smit H. 2014b - Torrenticolid water mites (Acari: Hydrachnidia: Torrenticolidae) from Malaysian Borneo — Zootaxa, 3840(1): 1-72

Pešić V., Smit H. 2015 - Two new species of the genus Atractides Koch, 1837 (Acari: Hydrachnidia: Hygrobatidae) with an updated checklist of the water mites of Thailand - Syst. Appl. Acarol., 20: 782-788. doi:10.11158/saa.20.7.6

Scharf B., Viehberg F.A. 2014 - New methods for collecting Ostracoda (Crustacea) in stony sediments with methodical remarks on the separation of ostracods from the sediment. —Crustaceana, 87(8-9): 1136-1147.

Smith I.M., Cook D.R., Gerecke R. 2015 - Revision of the status of some genus-level water mite taxa in the families Pionidae Thor, 1900, Aturidae Thor, 1900, and Nudomideopsidae Smith, 1990 (Acari: Hydrachnidiae) - Zootaxa, 3919: 111-156

Smit H. 2016 - The water mite family Aturidae Thor, 1900 from Southeast Asia (Acari: Hydrachnidia) with the description of one new genus and 14 new species - Acarologia, 56(3): 341-365. doi:10.1051/acarologia/20162248

Tuzovskij P.V. 2009a - A new water mite species of the genus Acucapito (Acariformes: Acucapitidae) from Vietnam - Zoosystematica Rossica, 18(2): 212-217.
Tuzovskij P.V. 2009b -A new water mite species of the genus Monatractides (Acariformes: Torrenticolidae) from Vietnam - Acarologia, 49(3-4): 179-183.

Tuzovskij P.V. 2013a - New water mite species (Acari, Hydrachnidia) from Vietnam - Zootaxa, 3700: 547560. doi:10.11646/zootaxa.3700.4.3

Tuzovskij P.V. 2013b - Two new water mite species of the genus Neumania Lebert (Acariformes, Hydrachnidia, Unionicoliodae) - Acarina, 21(2): 114-122.

Tuzovsky P.V. 2014 - Description of a new water mite species of the genus Sigthoria Koenike (Acari, Hydrachnidia, Anisitsiellidae) from Vietnam - Acarina, 22(1): 24-28.

Tuzovsky P.V. 2015 - Description of a new water mite species of the genus Hydrodroma Koch (Acari, Hydrachnidia, Hydrodromidae) from Vietnam - Acarina, 23(2): 152-155.

Uchida T., Imamura T. 1951 - Some water mites from China. - J. Fac. Sci., Hokkaido Univ., Ser. 6, Zool., 10: 324-358.

Viets K. 1935 - Die Wassermilben von Sumatra, Java und Bali nach den Ergebnissen der Deutschen Limnologischen Sunda-Expedition - Arch. Hydrobiol., Suppl. 13, Trop. Binnengewässer, 5(3): 484-594, 5(4): 595-738, Suppl. 14, Trop. Binnengewässer, 6(1): 1-113.

Wiles P.R. 1991 - Rheophilic watermites (Acari: Hydrachnidia) from mainland Malaysia - Acarologia, 32: 41-56.

Wiles P.R. 1991 - The homology of glands and glandularia in the water mites (Acari: Hydrachnidia) - J. Nat. Hist., 31: 1237-1251. doi:10.1080/00222939700770671

Wiles P.R. 2004 - Water mites (Acari: Hydrachnidia) from South-East Asia, Thailand and Sulawesi Tenggara (Indonesia): descriptions of new species and new records - J. Nat. Hist., 38: 2153-2165. doi:10.1080/00222930310001617742

Yi T.-C., Jin D.-C. 2012 - Description of Sinaxonopsis unicucrus sp. nov. et gen. nov. (Acari: Hydrachnidia: Aturidae) from Anhui Province, China - Int. J. Acarol., 38: 402-409. doi:10.1080/01647954.2012.657802

\section{COPYRIGHT}

$((c)$ EY-No-ND Pešić V. and Smit H. Acarologia is under free license. This open-access article is distributed under the terms of the Creative Commons-BY-NC-ND which permits unrestricted non-commercial use, distribution, and reproduction in any medium, provided the original author and source are credited. 